\title{
Photosynthetic performance and photosynthesis-related gene expression coordinated in a shade-tolerant species Panax notoginseng under nitrogen regimes
}

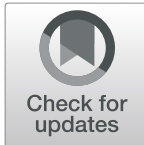

Jin-Yan Zhang ${ }^{1,2,3}$, Zhu Cun ${ }^{1,2,3}$ and Jun-Wen Chen ${ }^{1,2,3^{*}}$

\begin{abstract}
Background: Nitrogen $(\mathrm{N})$ is an essential component of photosynthetic apparatus. However, the mechanism that photosynthetic capacity is suppressed by $\mathrm{N}$ is not completely understood. Photosynthetic capacity and photosynthesis-related genes were comparatively analyzed in a shade-tolerant species Panax notoginseng grown under the levels of low $N(L N)$, moderate $N(M N)$ and high $N(H N)$.

Results: Photosynthetic assimilation was significantly suppressed in the LN- and HN-grown plants. Compared with the MN-grown plants, the HN-grown plants showed thicker anatomic structure and larger chloroplast accompanied with decreased ratio of mesophyll conductance $\left(g_{m}\right)$ to Rubisco content $\left(g_{m} /\right.$ Rubisco) and lower Rubisco activity. Meanwhile, LN-grown plants displayed smaller chloroplast and accordingly lower internal conductance $\left(g_{i}\right)$. LN- and $\mathrm{HN}$-grown individuals allocated less $\mathrm{N}$ to light-harvesting system $\left(\mathrm{N}_{\mathrm{L}}\right)$ and carboxylation system $\left(\mathrm{N}_{C}\right)$, respectively. $\mathrm{N}$ surplus negatively affected the expression of genes in Car biosynthesis (GGPS, DXR, PSY, IPI and DXS). The LN individuals outperformed others with respect to non-photochemical quenching. The expression of genes (FBA, PGK, $R A F 2, G A P C, C A B, P S B A$ and $P S B H$ ) encoding enzymes of Calvin cycle and structural protein of light reaction were obviously repressed in the $L N$ individuals, accompanying with a reduction in Rubisco content and activity. Correspondingly, the expression of genes encoding RAF2, RPI4, CAB and PetE were repressed in the HN-grown plants.

Conclusions: LN-induced depression of photosynthetic capacity might be caused by the deceleration on Calvin cycle and light reaction of photosynthesis, and $\mathrm{HN}$-induced depression of ones might derive from an increase in the form of inactivated Rubisco.
\end{abstract}

Keywords: Photosynthesis, Rubisco, Chloroplast, Non-photochemical quenching, Nitrogen, Panax notoginseng

\footnotetext{
* Correspondence: cjw31412@hotmail.com

'College of Agronomy \& Biotechnology, Yunnan Agricultural University, Kunming 650201, China

${ }^{2}$ Key Laboratory of Medical Plant Biology of Yunnan Province, Yunnan Agricultural University, Kunming 650201, China

Full list of author information is available at the end of the article
}

C C The Author(s). 2020 Open Access This article is licensed under a Creative Commons Attribution 4.0 International License, which permits use, sharing, adaptation, distribution and reproduction in any medium or format, as long as you give appropriate credit to the original author(s) and the source, provide a link to the Creative Commons licence, and indicate if changes were made. The images or other third party material in this article are included in the article's Creative Commons licence, unless indicated otherwise in a credit line to the material. If material is not included in the article's Creative Commons licence and your intended use is not permitted by statutory regulation or exceeds the permitted use, you will need to obtain permission directly from the copyright holder. To view a copy of this licence, visit http://creativecommons.org/licenses/by/4.0/. The Creative Commons Public Domain Dedication waiver (http://creativecommons.org/publicdomain/zero/1.0/) applies to the data made available in this article, unless otherwise stated in a credit line to the data. 


\section{Background}

Nitrogen $(\mathrm{N})$ is a major limiting factor in natural ecosystems and in most agricultural systems $[1,2] . \mathrm{N}$ is regarded as a necessary component of numerous biomolecules, such as DNA, RNA, proteins, chlorophyll (Chl) and cell envelope [3, 4]. N shortage results in enormous changes in plant morphology and even destroys the balance of biological process, including $\mathrm{N}$ metabolism and photosynthesis [5, 6]. N-deficient crops show the premature of leaves, and reduce leaf area expansion, plant height and ultimately yield of their own [5-9]. On the other hand, excessive $\mathrm{N}$ supply makes leaves dark green and stems frail and immature, and consequently cause an imbalance between the vegetative and reproductive growth [10-12]; For example, excessive N supply considerably reduces the biomass of cucumber (Cucumis sativus) [13] and of tomato (Lycopersicon esculentum) [14] . However, $\mathrm{N}$ surplus in plants receives relatively little attentions in comparison with $\mathrm{N}$ deficiency over the past decades.

It has been commonly accepted that photosynthesis is highly influenced by leaf anatomy and chloroplast ultrastructure. HN-grown Arabidopsis. thaliana displays thicker upper epidermises, lower epidermises, spongy tissue and palisade tissue, and increased thickness of anatomic structure would not facilitate $\mathrm{CO}_{2}$ diffusion in the liquid phase of mesophyll cells [15]. N deficiency exhibits small chloroplast with lower internal conductance $\left(g_{i}\right)$ [16], and a large chloroplast with well-developed grana under high-N application has been reported in summer maize [17]. Indeed, Photosynthesis-related components are strongly regulated by leaf $\mathrm{N}$ and photosynthetic capacity is closely related to $\mathrm{N}$ content since more than $50 \%$ of total leaf $\mathrm{N}$ is allocated to photosynthetic machinery and proteins of Calvin cycle represent the majority of leaf $\mathrm{N}$ [18-21]. In leaves of developing maize (Zea mays), $\mathrm{N}$ deficiency results in an obvious decrease in photosynthesis with an reduction in activities of phosphor enolpyruvate carboxylase (PEPC), pyruvate orthophosphate di-kinase (PPDK) and ribulose 1, 5bisphosphate carboxylase (Rubisco) [17, 22-24]. A reduction in content of Rubisco and in effective and maximum quantum yield of photosystem II $\left(\Delta F_{\mathrm{v}} / F_{\mathrm{m}} \& F_{\mathrm{v}} /\right.$ $F_{\mathrm{m}}$ ) has been recorded in $A$. thaliana and Oryza sative grown under $\mathrm{N}$ deficiency condition $[25,26]$. Likewise, Rubisco carboxylase activity considerably declines in spinach (Spinacia oleracea) and cassava (Manihot esculenta) due to $\mathrm{N}$ deficiency $[27,28]$. On the other hand, negative responses of photosynthetic capacity to excess $\mathrm{N}$, including decreased Rubisco activity, lower $\mathrm{N}$ allocation to light-harvesting system $\left(\mathrm{N}_{\mathrm{L}}\right)$ and lower photosynthetic efficiency, have been observed in field-grown wheat [29], rice [30] and cotton [31]. In general, the relationship between $\mathrm{N}$ levels and photosynthesis is nonlinear in a sufficiently broad range of leaf $\mathrm{N}$ content $[32,33]$. However, relatively little is known about its molecular mechanism on the nonlinear relationship between leaf $\mathrm{N}$ and photosynthesis.

N-suboptimal plants would suffer from greater excess of light energy, and this could produce excessive reactive oxygen species (ROS) [34]. Plants has employed a series of photoprotective mechanism to survive long periods of no-optimal $\mathrm{N}$ regimes. Non-photochemical quenching (NPQ) of excess light energy within the light-harvesting antennae of PSII (LHCII) are believed as an effective photoprotective mechanisms, as observed in A. thaliana plants subjected to low nitrogen (LN) $[26,35,36]$ and in Coffea Arabica [37] and Lavandula angustifolia [38]. Excess $\mathrm{N}$ supply in benthic diatom (Entomoneis paludosa) [39] have revealed an up-regulation of xanthophyll cycle, which reduce the efficiency of PSII photochemistry and enhance NPQ. In addition, several studies have highlighted a positive effect of glycolytic pathway and pentose phosphate pathway (PPP) on energy and carbon balance in $\mathrm{N}$ stressed plants $[40,41]$. Unexpectedly, molecular mechanisms of photoprotection are not completely clear in the $\mathrm{N}$-stressed non-model species, especially in a shadetolerant plant.

Comparative transcriptomes have revealed that unigenes expression of Chl biosynthesis, Calvin cycle and ribosomal proteins were decreased in Scenedesmus acuminatus under high $\mathrm{N}$ (HN) supply [42]. Up-regulated gene transcripts are predominantly matched in kinds of amino acid metabolism, transport and stress, whereas repressed transcripts are overrepresented in categories of hormone metabolism and redox control in roots of $A$. thaliana under $\mathrm{N}$ deficiency [43]. During periods of $\mathrm{N}$ limitation, gata transcription factor $(G N C)$, a gene regulating carbon $(\mathrm{C})$ and $\mathrm{N}$ metabolism, operates to support A. thaliana survival by elevating $\mathrm{Chl}$ biosynthesis [44]. Genes encoding enzymes for $\mathrm{C}$ skeleton production are down-regulated in spinach plants under $\mathrm{N}$-starvation, and plants also significantly show low contents of amino acid and high levels of glucose and consequently decelerate growth [45]. Light reaction center of photosynthesis by extrinsic proteins labled as $P s b O, P s b P, P s b Q$, $P s b R, P s b U$ and PsbV are suppressed in Synechocystis under $\mathrm{N}$ stress [46]. PsbS protein is activated by the acidity of thylakoid lumen in $A$. thaliana plants under $\mathrm{N}$-stressed condition [47]. In addition, the expression of $N R$ and GOGAT was dramatically up-regulated in the cucumber exposed to $\mathrm{HN}$ [48]. Surprisingly, relatively less investigation has been conducted to elucidate the correlation of photosynthesis-related genes expression with photosynthetic performance in the context of $\mathrm{N}$.

Panax notoginseng (Burkill) F. H. Chen (Sanqi in Chinese) is a typically shade-tolerant species from the family of Araliaceae [49-51], In our previous researches, $P$. 
notoginseng is believed to be highly sensitive to high light, and $10 \%$ of full sunlight is suitable for its growth [50,52]. Besides, the development and growth of $P$. notoginseng is highly sensitive to high $\mathrm{N}$ [53-55]. HN application considerably enhance rust cracking, root decay and mortality rate of $P$. notoginseng [56]. Indeed, significant decreases in root, stem and leaf biomass have been observed in $P$. notoginseng grown under LN, along with narrow and yellow leaves $[57,58]$. However, these previous studies have mainly focused on effects of $\mathrm{N}$ input on agronomic traits, yield, and plant growth. Nowadays, the molecular mechanism of the sensitivity of $P$. notoginseng to $\mathrm{N}$ is still unclear.

Different $\mathrm{N}$ levels were applied to $P$. notoginseng, and photosynthetic capacity, photoprotection and photosynthetic pigments were comparatively analyzed in the plants grown under low $\mathrm{N}(\mathrm{LN})$, moderate $\mathrm{N}(\mathrm{MN})$ and high $\mathrm{N}(\mathrm{HN})$. Meanwhile, a comprehensive transcriptome was conducted to elucidate the expression of photosynthesis-related gene. The objective of our study was to elucidate the photosynthetic performance and the expression of photosynthesis-related genes in the typically shade-tolerant and $\mathrm{N}$-sensitive plant $P$. notoginseng under different levels of $\mathrm{N}$, and it was anticipated that photosynthetic performance might be coordinated with the expression of photosynthesis-related genes.

\section{Results}

Effect of $\mathrm{N}$ regimes on plant growth and leaf gas change $\mathrm{HN}$-grown leaves were pretty dark-green, and LNgrown leaves were significantly smaller and yellowish (Additional file 1: Figure S1a). HN-grown plants possessed a low survival rate (Additional file 1: Figure $\mathrm{S} 1 \mathrm{~b})$. LN-grown leaves were dramatically reduced in the thickness of upper epidermis, lower epidermis, spongy tissue and palisade tissue, and biomass of leaf was significantly reduced in $\mathrm{LN}$ and $\mathrm{HN}$ treatments
(Table 1). On the other hand, LN significantly decreased the size of chloroplasts accompanied with a reduction in chloroplast exposed to intercellular air space per unit leaf area $\left(\mathrm{S}_{\mathrm{c}}\right)$, and correspondlingly an increase in the size of chloroplasts was observed in $P$. notoginseng under excessive $\mathrm{N}$ supply (Fig. $1 \mathrm{c}$; Table 2). The LN plants and HN plants showed 52.7 and $96.8 \%$ lower liquid phase $\left(\mathrm{g}_{\text {lip }}\right)$ than the $\mathrm{MN}$ plants, respectively. $\mathrm{g}_{\text {lip }}$ can be expressed as glip $=\mathrm{C}_{\text {lip }} \times \mathrm{S}_{\mathrm{C}}$, therefore, conductance per unit of exposed chloroplast surface area $\left(\mathrm{C}_{\text {lip }}\right)$ is one of a determinant of $\mathrm{g}_{\text {lip }}$. $\mathrm{C}_{\text {lip }}$ were reduced in $\mathrm{HN}$-grown plants as compared to the $\mathrm{MN}$-grown individuals. Internal $\mathrm{CO}_{2}$ condutance $\left(\mathrm{g}_{\mathrm{i}}\right)$ is mainly determined by $\mathrm{g}_{\text {lip }}$, and $\mathrm{LN}$-and $\mathrm{HN}$-grown plants was decreased in $\mathrm{g}_{\mathrm{i}}$ (Table 2).

\section{$\mathrm{N}$-induced changes in photosynthetic capacity}

The leaf exhibited a significant difference in a response of net photosynthetic assimilation $\left(A_{\text {net }}\right)$ to incident photosynthetic photon flux density (PPFD) and to internal leaf $\mathrm{CO}_{2}$ concentrations $\left(C_{\mathrm{i}}\right)$ within $\mathrm{N}$ regimes (Fig. 2). The maximum net photosynthetic assimilation $\left(A_{\max }\right), \mathrm{CO}_{2}$ response curves and carboxylation efficiency $(C E)$, maximum electron transfer rate $\left(J_{\max }\right)$ and maximum carboxylation efficiency $\left(V_{\text {cmax }}\right)$ were highest in MN- grown plants; however, these variables did not show apparent differences between LN and HN individuals except for $A_{\max }$ (Table 3). $\mathrm{N}$ allocation to the photosynthetic system $\left(\mathrm{N}_{\text {photo }}\right)$ is the sum of $\mathrm{N}$ allocation to the carboxylation system $\left(\mathrm{N}_{\mathrm{C}}\right)$, the bioenergetics component $\left(\mathrm{N}_{\mathrm{B}}\right)$ and the light-harvesting system $\left(\mathrm{N}_{\mathrm{L}}\right)$. N content per unit leaf area (SLN) was increased significantly with the increase in $\mathrm{N}$ application (Table 3). HN treatment caused a significant increase in $\mathrm{N}_{\mathrm{L}}$, whereas there is a significant reduction in $\mathrm{N}_{\mathrm{C}}$ in $\mathrm{HN}$-grown plants (Fig. 3 a). Most importantly, photosynthetic $\mathrm{N}$ use efficiency (PNUE) was significantly decreased from 45.2

Table 1 Effects of nitrogen regimes on the leaf morphology, anatomy and biomass in a shade-tolerant plant Panax notoginseng

\begin{tabular}{|c|c|c|c|}
\hline \multirow[t]{2}{*}{ Variables } & \multirow[b]{2}{*}{ LN } & \multicolumn{2}{|l|}{ Nitrogen level } \\
\hline & & MN & $\mathrm{HN}$ \\
\hline Upper epidermis $(\mu \mathrm{m})$ & $11.209 \pm 0.024 c$ & $17.694 \pm 1.927 \mathrm{a}$ & $14.738 \pm 0.269 b$ \\
\hline Lower epidermis $(\mu \mathrm{m})$ & $10.590 \pm 1.027 c$ & $13.177 \pm 2.186 \mathrm{a}$ & $11.420 \pm 0.918 b$ \\
\hline Spongy tissue $(\mu \mathrm{m})$ & $42.551 \pm 2.194 \mathrm{C}$ & $70.378 \pm 0.182 \mathrm{a}$ & $56.518 \pm 0.189 b$ \\
\hline Palisade tissue ( $\mu \mathrm{m})$ & $17.069 \pm 1.283 c$ & $32.867 \pm 0.173 a$ & $24.490 \pm 1.825 b$ \\
\hline Palisade/spongy & $0.401 \pm 0.002$ & $0.467 \pm 0.016$ & $0.433 \pm 0.016$ \\
\hline Leaf length $(\mathrm{cm})$ & $6.484 \pm 1.980 c$ & $7.515 \pm 1.068 \mathrm{a}$ & $6.795 \pm 1.238 b$ \\
\hline Max width $(\mathrm{cm})$ & $2.777 \pm 0.698 c$ & $3.114 \pm 0.621 \mathrm{ab}$ & $3.273 \pm 0.519 a$ \\
\hline Leaf length/max width & $2.341 \pm 1.339$ & $2.413 \pm 0.8445$ & $2.076 \pm 0.879$ \\
\hline Leaf dry weight (g plant ${ }^{-1}$ ) & $0.413 \pm 0.040 c$ & $0.545 \pm 0.025 \mathrm{a}$ & $0.496 \pm 0.064 b$ \\
\hline Total dry weight (g plant ${ }^{-1}$ ) & $1.068 \pm 0.294 c$ & $1.649 \pm 0.181 \mathrm{a}$ & $1.524 \pm 0.088 b$ \\
\hline
\end{tabular}

Values are means \pm SD. $(n=7)$. Different letters among nitrogen regimes indicate significant difference $(P \leq 0.05)$ 

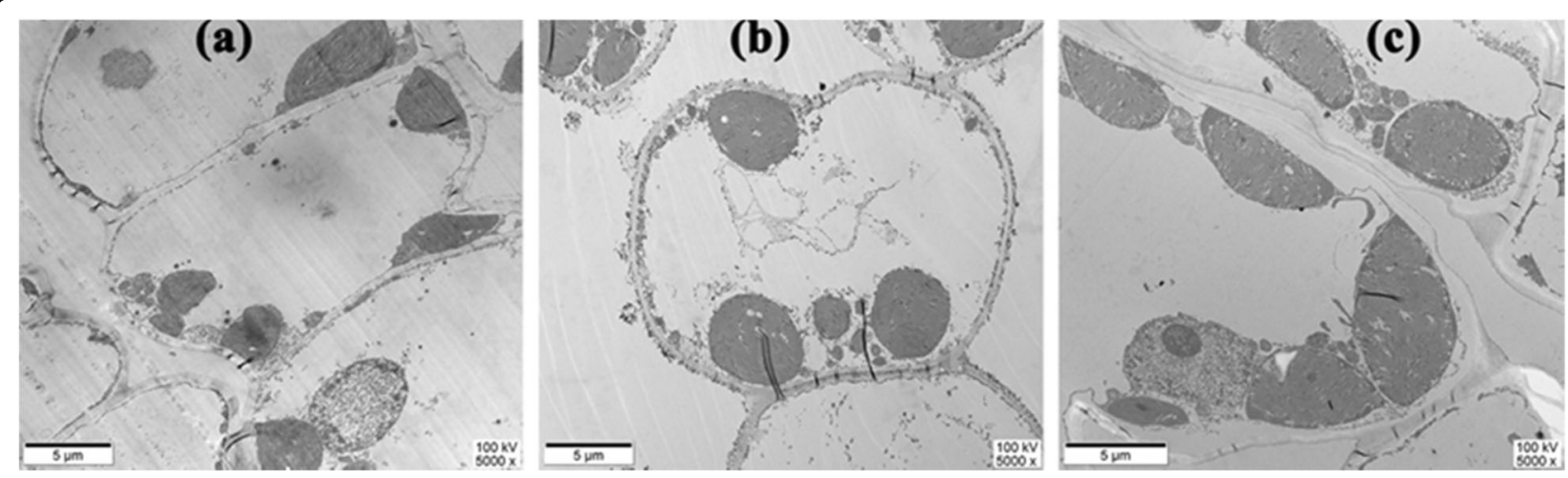

Fig. 1 Electron micrograph of chloroplast with low(a), moderate(b) and high(c) nitrogen level were taken at 5000, 5000 and 5000 times, respectively

to $20.3 \%$ with an increase in $\mathrm{N}$ supply (Fig. 3 b). These results support that high $\mathrm{N}_{\text {photo }}$ did not trigger an increase in PNUE.

SLN and Rubisco content were greater when plants were exposed to high $\mathrm{N}$ as compared with ones to moderate and low N (Additional file 2: Figure S2; Tables 2, 3). MN treatment exhibited $44.4-98.4 \%$ more Rubisco activity than two other treatments (Table 2). There were no significant differences in stomatal conductance $\left(\mathrm{g}_{\mathrm{s}}\right)$ within treatments, but $g_{m}$ were higher in HN-grown individuals (Table 2). HN-grown plants had a decreased ratio of $g_{m} /$ Rubisco content and a lower Rubisco specific activity than two other treatments (Table 2).

\section{Photosynthetic electronic transport}

The responses of photosynthetic electronic transport to continuous steady-state light were markedly different among $\mathrm{N}$ regimes (Additional file 3: Figure S3; Fig. 4). In the light response curves, the minimum values of PSII maximum quantum efficiency $\left(F_{\mathrm{v}}{ }^{\prime} / F_{\mathrm{m}}{ }^{\prime}\right)$, PSII photochemical quantum yield ( $\left.\Phi_{\mathrm{PSII}}\right)$, photochemical quenching $(\mathrm{qP})$ as well as PSII total electron transport rate $\left(J_{\mathrm{T}}\right)$, rate of electron transport for oxidation reaction $\left(J_{\mathrm{O}}\right)$, carboxylation reaction $\left(J_{\mathrm{C}}\right)$ and the maximum values of non-photochemical quenching (NPQ) were generally recorded in the LN individuals, the maximum value of $F_{\mathrm{v}}{ }^{\prime} / F_{\mathrm{m}}{ }^{\prime}, \Phi_{\mathrm{PSII}}, \mathrm{qP}$ as well as $J_{\mathrm{T}}, J_{\mathrm{O}}, J_{\mathrm{C}}$ were obtained in the MN ones (Additional file 3: Figure S3; Fig. 4).

\section{Changes in photosynthetic-related pigments}

The amounts of $\beta$-carotene ( $\beta$-Cars) and the ratio of $(\mathrm{V}+\mathrm{A}+\mathrm{Z}) / \mathrm{Chl}$ were enhanced in $\mathrm{LN}$ individuals, whereas total Chl decreased (Table 4). LN resulted in a decrease in neoxanthin $(\mathrm{N})$ and lutein $(\mathrm{L})$, and an increase

Table 2 Effects of $\mathrm{N}$ regimes on leaf photosynthesis in Panax notoginseng

\begin{tabular}{|c|c|c|c|}
\hline Variables & LN & MN & $\mathrm{HN}$ \\
\hline$\overline{g_{s}}\left(\mathrm{~mol} \mathrm{CO} \mathrm{m}^{-2} \cdot \mathrm{s}^{-1}\right)$ & $0.05 \pm 0.02 \mathrm{a}$ & $0.03 \pm 0.02 \mathrm{ab}$ & $0.03 \pm 0.02 \mathrm{ab}$ \\
\hline $\mathrm{gm}_{\mathrm{m}}\left(\mathrm{mol} \mathrm{CO} \mathrm{CO}^{-2} \cdot \mathrm{s}^{-1}\right)$ & $0.09 \pm 0.01 c$ & $0.26 \pm 0.04 b$ & $0.36 \pm 0.02 \mathrm{a}$ \\
\hline $\mathrm{R}_{\mathrm{d}}\left(\mu \mathrm{mol} \mathrm{CO}_{2} \mathrm{~m}^{-2} \cdot \mathrm{s}^{-1}\right)$ & $1.0 \pm 0.04 \mathrm{a}$ & $0.52 \pm 0.02 b$ & $0.57 \pm 0.03 b$ \\
\hline $\mathrm{g}_{\text {lip }}\left(\mathrm{mol} \mathrm{CO} \mathrm{CO} \mathrm{m}^{-2} \cdot \mathrm{s}^{-1}\right)$ & $2.61 \pm 0.08 b$ & $5.52 \pm 0.03 a$ & $0.183 \pm 0.09 c$ \\
\hline$C_{c}\left(\mu \mathrm{mol} \mathrm{CO}_{2} \mathrm{~m}^{-2} \cdot \mathrm{s}^{-1}\right)$ & $199.53 \pm 8.27 b$ & $265.45 \pm 7.31 \mathrm{ab}$ & $291.58 \pm 9.15 \mathrm{a}$ \\
\hline $\left.\mathrm{S}(\mathrm{mol} \mathrm{mol})^{-1}\right)$ & $844.15 \pm 7.56 b$ & $1057.25 \pm 5.41 \mathrm{a}$ & $860.16 \pm 3.89 b$ \\
\hline $\mathrm{S}^{*}\left(\mathrm{~mol} \mathrm{~mol}{ }^{-1}\right)$ & $739.39 \pm 95.61 b$ & $983.75 \pm 67.32 \mathrm{a}$ & $753.41 \pm 90.34 b$ \\
\hline Rubisco activity (nmol/min/g) & $0.643 \pm 0.24 c$ & $40.51 \pm 5.39 a$ & $22.51 \pm 4.89 b$ \\
\hline Rubisco content $\left(\mu \mathrm{g} / \mathrm{g}^{-1}\right)$ & $6.931 \pm 0.36 c$ & $10.057 \pm 0.67 b$ & $70.494 \pm 0.32 \mathrm{a}$ \\
\hline $\mathrm{S}_{\mathrm{c}}\left(\mathrm{m}^{2} \mathrm{~m}^{-2}\right)$ & $8.42 \pm 1.25 b$ & $12.01 \pm 1.65 \mathrm{a}$ & $13.15 \pm 0.56 \mathrm{a}$ \\
\hline$C_{\text {lip }}\left(\mathrm{mol} \mathrm{CO} 2 \mathrm{~m}^{-2} \cdot \mathrm{s}^{-1}\right)$ & $0.31 \pm 0.06 \mathrm{ab}$ & $0.46 \pm 0.02 \mathrm{a}$ & $0.02 \pm 0.01 b$ \\
\hline $\mathrm{gi}_{\mathrm{i}}\left(\mathrm{mol} \mathrm{CO} \mathrm{m}^{-2} \cdot \mathrm{s}^{-1}\right)$ & $0.13 \pm 0.01 b$ & $0.35 \pm 0.04 \mathrm{a}$ & $0.12 \pm 0.05 b$ \\
\hline $\mathrm{g}_{\mathrm{m}} /$ Rubisco content & $12.99 \pm 1.23 b$ & $25.81 \pm 1.90 \mathrm{a}$ & $5.12 \pm 0.78 c$ \\
\hline
\end{tabular}

Values are means \pm SD. $(n=7)$. Different letters among nitrogen regimes indicate significant difference $(P \leq 0.05)$. $g_{s}:$ stomatal conductance; $g_{m}:$ mesophyll conductance; $\mathrm{R}_{\mathrm{d}}$ : dark respiration rate; $\mathrm{g}_{\text {lip }}$ : liquid phase; $\mathrm{C}_{\mathrm{c}}$ : chloroplastic $\mathrm{CO}_{2}$ concentration; $\mathrm{S}$ : the specificity factor of Rubisco for $\mathrm{O}_{2}$ and $\mathrm{CO}_{2} ; \mathrm{S}^{*}$ : apparent Rubisco specificity; $\mathrm{S}_{c}$ : chloroplast exposed to intercellular air space per unit leaf area; $\mathrm{C}_{\text {lip: }}$ : conductance per unit of exposed chloroplast surface area; $g_{i}$ : internal $\mathrm{CO} 2$ condutance 


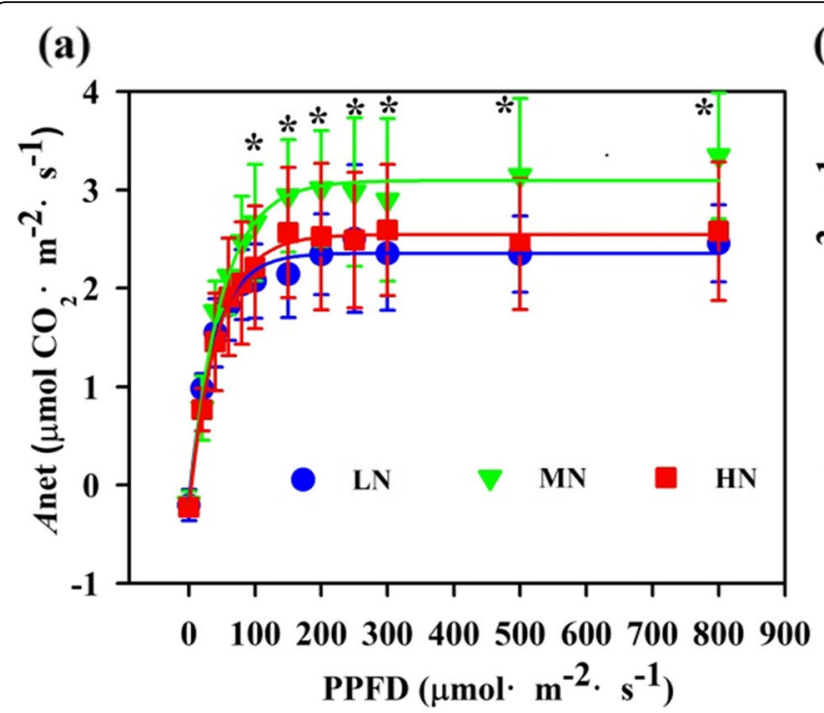

(b)

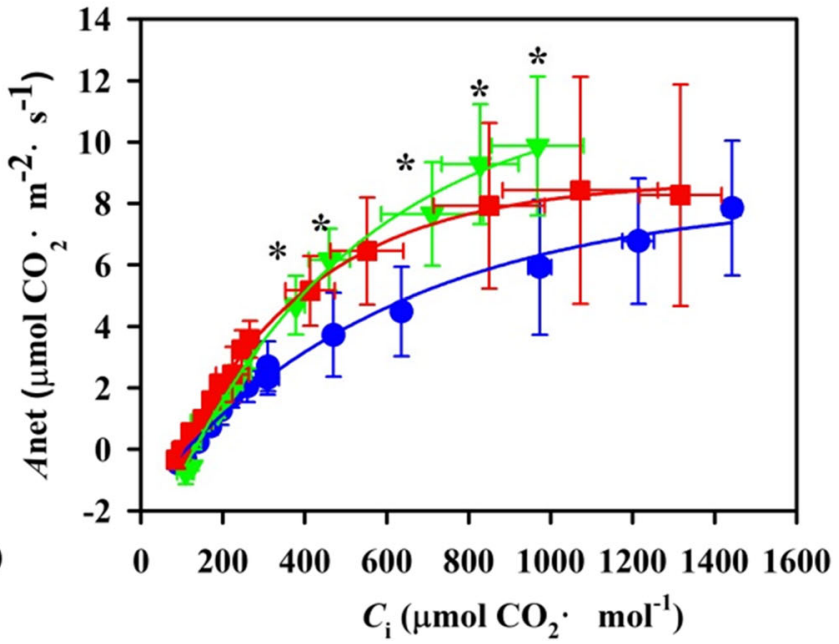

Fig. 2 a Response of net photosynthetic rate $\left(A_{\text {net }}\right)$ to photosynthetic photon flux density (PPFD) in Panax notoginseng grown under low nitrogen $(\mathrm{LN})$, moderate nitrogen $(\mathrm{MN})$, high nitrogen $(\mathrm{HN})$. $\mathbf{b}$ The change of net photosynthetic assimilation $\left(A_{\text {net }}\right)$ with intercellular $\mathrm{CO}_{2}$ concentration $\left(C_{\mathrm{i}}\right)$ in Panax notoginseng grown under different nitrogen levels. Values for each point were means \pm SD $(n=7)$. Significant differences are indicated by asterisks (ANOVA; $P$ values $\leq 0.05$ )

in violaxanthin $(\mathrm{V})$, antheraxanthin $(\mathrm{A})$, and zeaxanthin $(\mathrm{Z})$. Violaxanthin de-epoxide activity $((\mathrm{A}+\mathrm{Z}) /(\mathrm{V}+\mathrm{A}+\mathrm{Z}))$ was greatest in the LN ones (Table 4).

\section{Gene expression identification}

Compared to the MN individuals, 1391 and 895 genes were classified as differentially expressed genes (DEGs) in the LN and HN groups. Whereas, there were 428 DEGs in both LN- and HN- treatments (Fig. 5). In the LN group, 467 DEGs were up-regulated, and 924 DEGs were down-regulated. Two hundred ninety-four genes were up-regulated and 601 genes were suppressed in HN individuals (Additional file 4: Figure S4). Moreover, 963 and 467 DEGs were typically detected in LN, HN groups. Two DEG sets were subjected to 34 Gene ontology (GO) classes (Fig. 6). Under the classification of molecular function, "catalytic activity" were largely represented, followed by "binding" (Fig. 6 a). The GO enrichment was further analyzed to identify specific GO enrichment terms among DEG sets. Based on Kyoto Encyclopedia of Genes and Genomes (KEGG) pathway enrichment analysis, the DEGs in LN ones were categorized into photosynthesis, carbon fixation, $\mathrm{N}$ metabolic, plant hormone signal transduction, starch and sucrose metabolism and galactose metabolism, the DEGs in HN ones were significantly overrepresented in pathway of citrate cycle (TCA cycle), alpha-Linolenic acid metabolism, carbon fixation in photosynthetic organism, $\mathrm{N}$ metabolism and galactose metabolism (Fig. 6 b). In addition, the first 13 pathways widely related to the mechanism about photosynthesis and photo-protection were explored among KEGG enrich

Table 3 Steady-state photosynthetic-related traits in Panax notoginseng under different levels of nitrogen

\begin{tabular}{llll}
\hline Variables & Nitrogen level & & \\
\cline { 2 - 3 } & LN & MN & $H N$ \\
\hline$A_{\max }\left(\mu \mathrm{mol} \cdot \mathrm{m}^{-2} \cdot \mathrm{s}^{-1}\right)$ & $2.378 \pm 0.261 \mathrm{c}$ & $3.437 \pm 0.241 \mathrm{a}$ & $2.600 \pm 0.165 \mathrm{~b}$ \\
$\mathrm{CE}\left(\mathrm{mol} \cdot \mathrm{mol}^{-1}\right)$ & $0.017 \pm 0.002 \mathrm{ab}$ & $0.022 \pm 0.003 \mathrm{a}$ & $0.018 \pm 0.005 \mathrm{ab}$ \\
$\Gamma^{*}\left(\mu \mathrm{mol} \cdot \mathrm{mol}^{-1}\right)$ & $124.399 \pm 8.014 \mathrm{a}$ & $99.259 \pm 10.957 \mathrm{~b}$ & $122.121 \pm 21.084 \mathrm{ab}$ \\
$J_{\max }\left(\mu \mathrm{mol} \cdot \mathrm{mol}^{-1}\right)$ & $66.558 \pm 6.123 \mathrm{~b}$ & $74.518 \pm 15.599 \mathrm{a}$ & $63.334 \pm 23.251 \mathrm{~b}$ \\
$V_{\mathrm{cmax}}\left(\mu \mathrm{mol} \cdot \mathrm{mol}^{-1}\right)$ & $16.480 \pm 1.821 \mathrm{~b}$ & $20.771 \pm 2.939 \mathrm{a}$ & $16.830 \pm 5.058 \mathrm{~b}$ \\
$J_{\max } / V_{\text {cmax }}$ & $4.059 \pm 0.127 \mathrm{ab}$ & $3.527 \pm 0.337 \mathrm{~b}$ & $4.329 \pm 0.106 \mathrm{a}$ \\
$\mathrm{SLN}\left(\mathrm{g} \mathrm{m}^{-2}\right)$ & $0.890 \pm 0.130 \mathrm{c}$ & $1.245 \pm 0.006 \mathrm{~b}$ & $2.178 \pm 0.348 \mathrm{a}$ \\
\hline
\end{tabular}

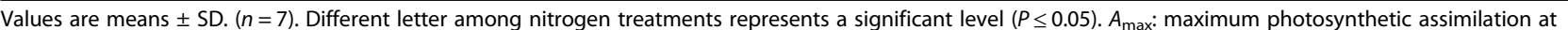
the saturating light; $C E$ : carboxylation efficiency; $\Gamma^{*}$ : carbon dioxide compensation point; $J_{\max }$ : maximum electron transfer rate; $V_{c m a x}$ : maximum carboxylation efficiency; SLN: nitrogen content per unit leaf area 

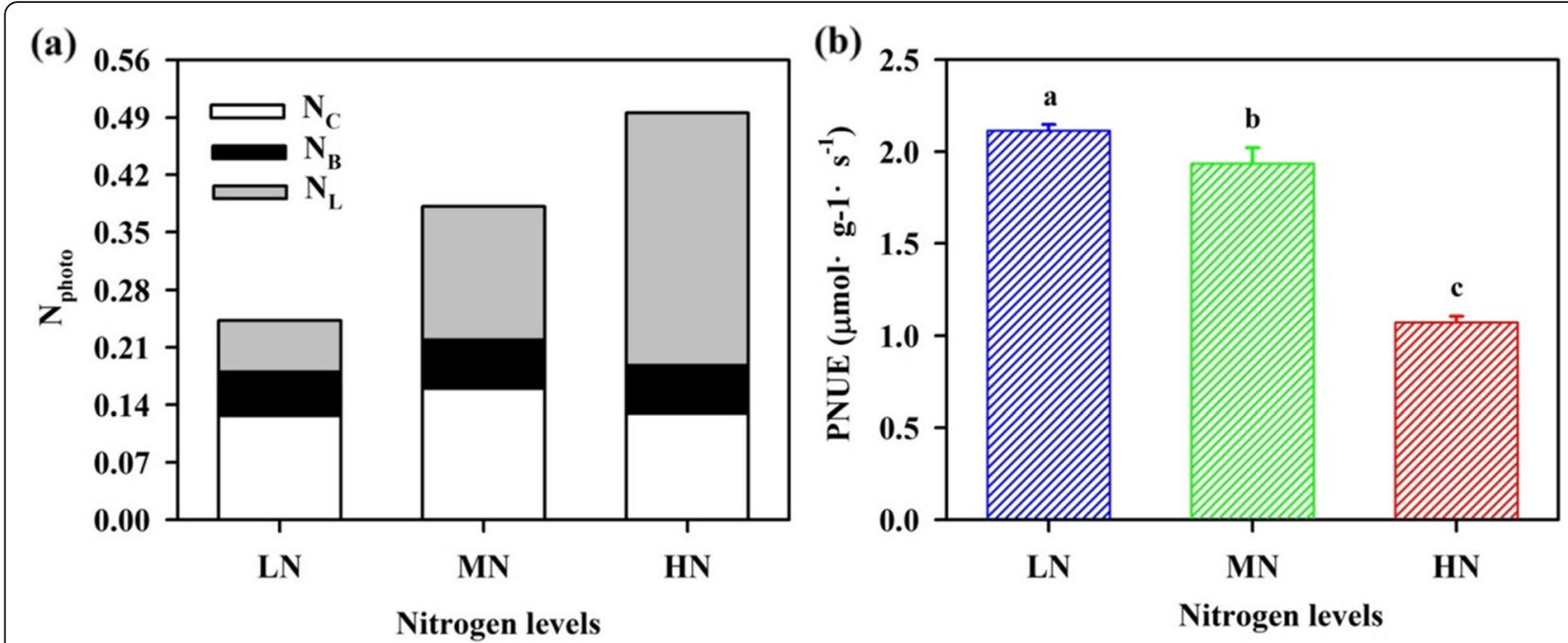

Fig. 3 Effects of different nitrogen levels on nitrogen distribution $(n=7)$ and photosynthetic nitrogen use efficiency $(n=7)$ in Panax notoginseng leaves. $N_{\text {photo: }}$ Photosynthetic apparatus; $\mathrm{N}_{C}$ : Carboxylation system; $\mathrm{N}_{\mathrm{B}}$ : Bioenergetics; $\mathrm{N}_{\llcorner}$: Light harvesting system; PNUE: Photosynthetic nitrogen use efficiency. Data are mean with bars depicting standard deviation $( \pm \mathrm{SD}$ ). Significant differences are indicated by letters (ANOVA; $P$ values $\leq 0.05$ )

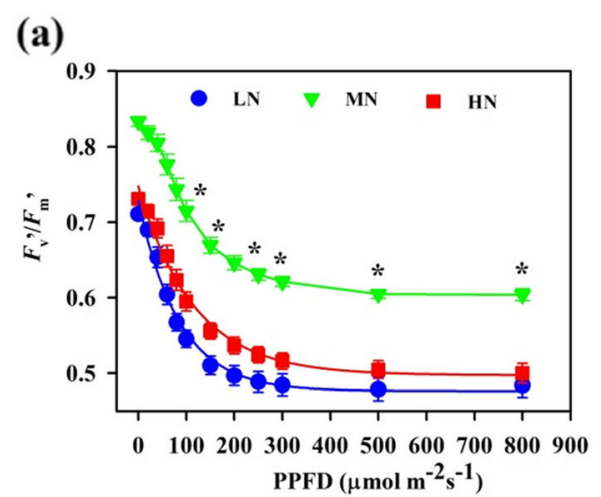

(b)

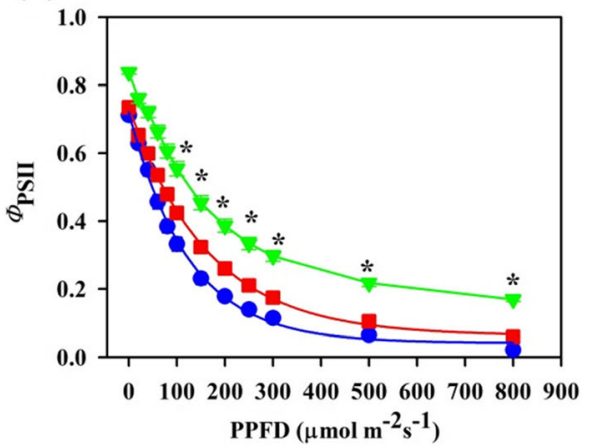

(c)

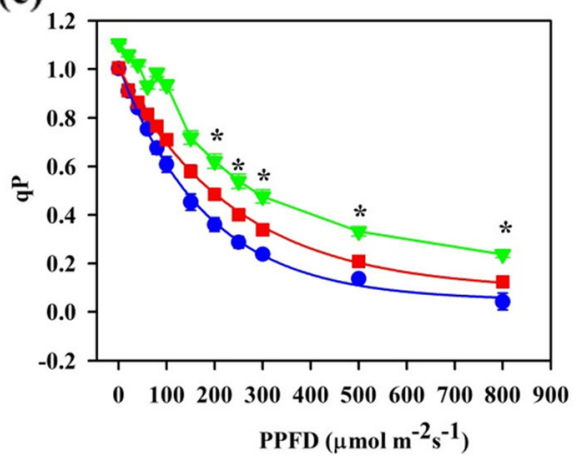

(d)

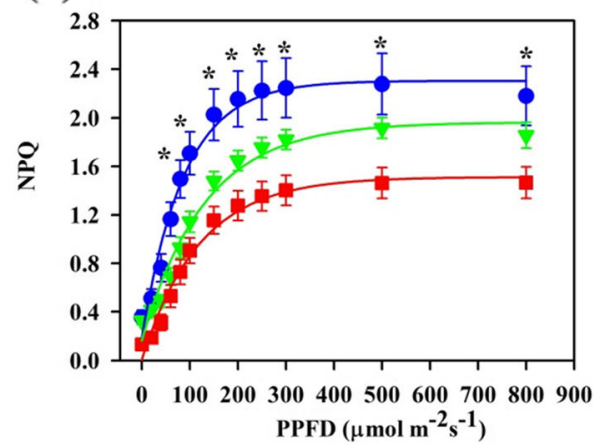

Fig. 4 Responses of PSII maximum quantum efficiency $\left(F_{\mathrm{v}}{ }^{\prime} / F_{\mathrm{m}}, \mathbf{a}\right)$, PSII photochemical quantum yield $\left(\Phi_{\mathrm{PS} \|}, \mathbf{b}\right)$, photochemical quenching $(\mathrm{qP}, \mathbf{c})$, non-photochemical quenching (NPQ, d) to photosynthetic photon flux density (PPFD) in Panax notoginseng grown under different levels of nitrogen. Values for each point were means \pm SD $(n=7)$. Significant differences are indicated by asterisks (ANOVA; $P$ values $\leq 0.05$ ) 
Table 4 Photosynthetic-related pigment in a shade-tolerant plant Panax notoginseng grown under different levels of nitrogen, means \pm SD were given $(n=7)$

\begin{tabular}{llll}
\hline Variables & \multicolumn{3}{l}{ Nitrogen Level } \\
\cline { 2 - 4 } & LN & $M N$ & $H N$ \\
\hline $\mathrm{N}\left(\mu \mathrm{g} \cdot \mathrm{cm}^{-2}\right)$ & $0.362 \pm 0.129 \mathrm{c}$ & $0.865 \pm 0.265 \mathrm{~b}$ & $1.643 \pm 0.332 \mathrm{a}$ \\
$\mathrm{V}\left(\mu \mathrm{g} \cdot \mathrm{cm}^{-2}\right)$ & $0.913 \pm 0.124 \mathrm{a}$ & $0.267 \pm 0.195 \mathrm{c}$ & $0.493 \pm 0.458 \mathrm{~b}$ \\
$\mathrm{~A}\left(\mu \mathrm{g} \cdot \mathrm{cm}^{-2}\right)$ & $0.213 \pm 0.019 \mathrm{a}$ & $0.043 \pm 0.072 \mathrm{c}$ & $0.153 \pm 0.079 \mathrm{~b}$ \\
$\mathrm{~L}\left(\mu \mathrm{g} \cdot \mathrm{cm}^{-2}\right)$ & $1.284 \pm 0.352 \mathrm{c}$ & $3.018 \pm 0.970 \mathrm{~b}$ & $5.852 \pm 0.926 \mathrm{a}$ \\
$\mathrm{Z}\left(\mu \mathrm{g} \cdot \mathrm{cm}^{-2}\right)$ & $0.194 \pm 0.023 \mathrm{a}$ & $0.032 \pm 0.048 \mathrm{c}$ & $0.073 \pm 0.201 \mathrm{~b}$ \\
$\mathrm{Chl}\left(\mathrm{g} \cdot \mathrm{cm}^{-2}\right)$ & $12.270 \pm 1.783 \mathrm{c}$ & $31.618 \pm 2.356 \mathrm{~b}$ & $60.101 \pm 2.455 \mathrm{a}$ \\
$\beta-C a r\left(\mathrm{~g} \cdot \mathrm{cm}^{-2}\right)$ & $4.08 \pm 2.14 \mathrm{a}$ & $1.59 \pm 0.69 \mathrm{c}$ & $2.95 \pm 0.69 \mathrm{~b}$ \\
$\mathrm{~V}+\mathrm{A}+\mathrm{Z}\left(\mathrm{g} \cdot \mathrm{cm}{ }^{-2}\right)$ & $1.314 \pm 0.023 \mathrm{a}$ & $0.332 \pm 0.035 \mathrm{c}$ & $0.712 \pm 0.043 \mathrm{~b}$ \\
$(\mathrm{~A}+\mathrm{Z}) /(\mathrm{V}+\mathrm{A}+\mathrm{Z})$ & $0.309 \pm 0.015 \mathrm{ab}$ & $0.226 \pm 0.017 \mathrm{~b}$ & $0.317 \pm 0.037 \mathrm{a}$ \\
$(\mathrm{V}+\mathrm{A}+\mathrm{Z}) / \mathrm{Chl}$ & $0.107 \pm 0.018 \mathrm{a}$ & $0.011 \pm 0.027 \mathrm{~b}$ & $0.012 \pm 0.028 \mathrm{~b}$
\end{tabular}

Different letter among nitrogen treatments represents a significant level $(P \leq$ $0.05) . V$ violaxanthin; $A$ antheraxanthin; $Z$ Zeaxanthin; $L$ Lutein; $N$ Neoxanthin; $\beta$-Car: $\beta$-Carotene

analysis of all annotated unigenes (Additional file 5: Table S1).

\section{Transcriptional changes}

GO enrichment analysis was presented and elucidated in Fig. 7. Enriched GO terms of further induced genes between two pairwise comparisons ( $\mathrm{MN}$ vs $\mathrm{LN}$., MN vs HN.) embraced photosynthesis, pigment metabolic process, carbohydrate catabolic process, thylakoid and so on. Common DEGs with suppressed expression were significantly enriched in cellular amino acid catabolic process, alpha-

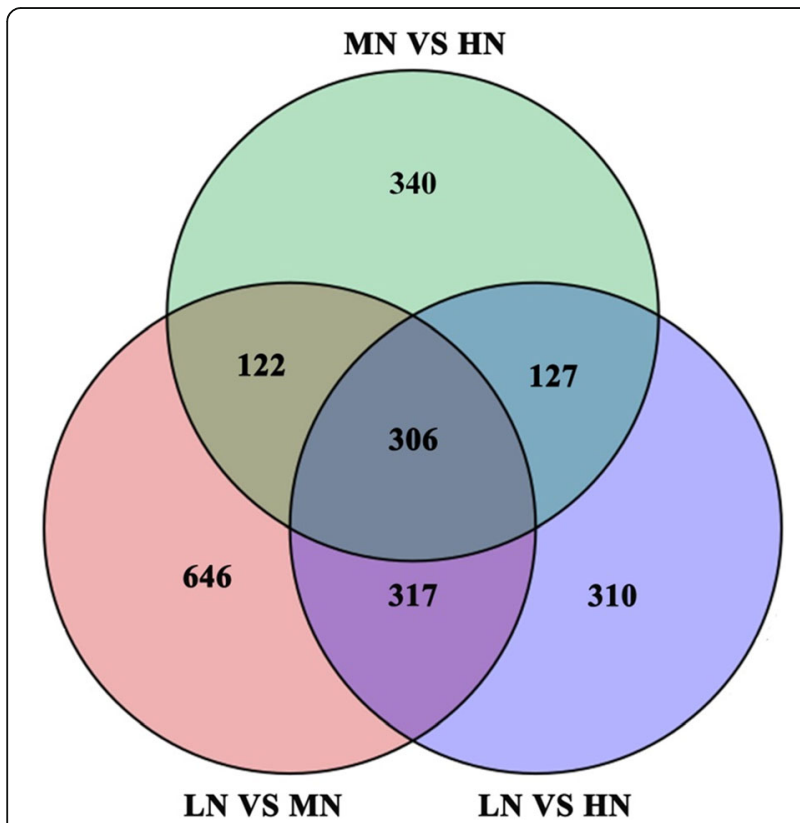

Fig. $\mathbf{5}$ Venn diagrams of differentially expressed genes (DEGs) in response to varied nitrogen level amino acid catabolic process, proline metabolic process and glutamine family amino acid metabolic (Fig. 7). KEGG pathway analysis was further certified distinct functional enrichments in biological process among common DEGs (Fig. 7 b, c), revealing that these induced expression of common DEGs were richen in TCA cycle, photosynthesis, carbon fixation in photosynthetic organism, glycolysis/ gluconeogenesis and carbon metabolism, and downregulated DEGs were primarily related to $\mathrm{N}$ metabolism, glutathione metabolism, biosynthesis of amino acids and starch and sucrose metabolism. In addition, a large number of specific DEGs involved in diverse biological processes were detected in the $\mathrm{MN}$ vs. $\mathrm{HN}$ ones, and response patterns in the LN and HN level also exhibited differences.

\section{Genes expression related to Calvin cycle and light reaction}

Interestingly, the expressions of the majority of genes encoding enzymes in Calvin cycle were down-regulated between LN and HN individuals, furthermore, the transcript levels of a substantial number of genes were reduced in LN ones (Additional file 6: Figure S5; Fig. 8). Expression of unigenes involved in photosystems II (e.g., $P s b A, P s b E, P s b F$, and $P s b H$ ) and photosystems I (e.g., $P s a N)$ were down-regulated between $\mathrm{LN}$ and $\mathrm{HN}$ individuals (Additional file 7: Figure S6a; Fig. 8), while the unigenes involved in $P s b S$ and PetE were up-regulated (Additional file 7: Figure S6b; Fig. 8).

\section{Photoprotection-related genes}

Both zeaxanthin epoxidase (ZEP) and violaxanthindeepoxidase $(V D E)$ genes are positively induced by $\mathrm{LN}$ level (Additional file 8: Figure S7a). Glucose-6-phosphate dehydrogenase $(G 6 P D H)$ and glutathione S-transferase (GSTs) involved in glucose metabolism was up-regulated in the LN individuals (Additional file 8: Figure S7b). Genes were found to be enriched in Chl degradation, and genes encoding chlorophyll b reductase (NYC) and red chlorophyll catabolite reductase $(R C C R)$ were up-regulated in the LN groups (Additional file 8: Figure S7c). Under LN levels, transcript levels of genes involved in nitrate reduction were up-regulated (Additional file 8: Figure S7d). Expressions of genes encoding phytoene synthase (PSY), geranyl pyrophosphate synthase (GGPS), 1-deoxy-D-xylulose-5-phosphate reductoisomerase $(D X R)$, isopentenyl pyrophosphate isomerase (IPI) and 1-deoxy-D-xylulose-5phosphate synthase $(D X S)$ were up-regulated in LN groups (Additional file 8: Figure S7e). In addition, a substantial number of pathway regulating photosynthesis and photoprotection were activated by $\mathrm{N}$-induction, including glutathione metabolism, $\mathrm{N}$ metabolism, carotenoid biosynthesis, photosynthesis-antenna proteins (Fig. 8). 


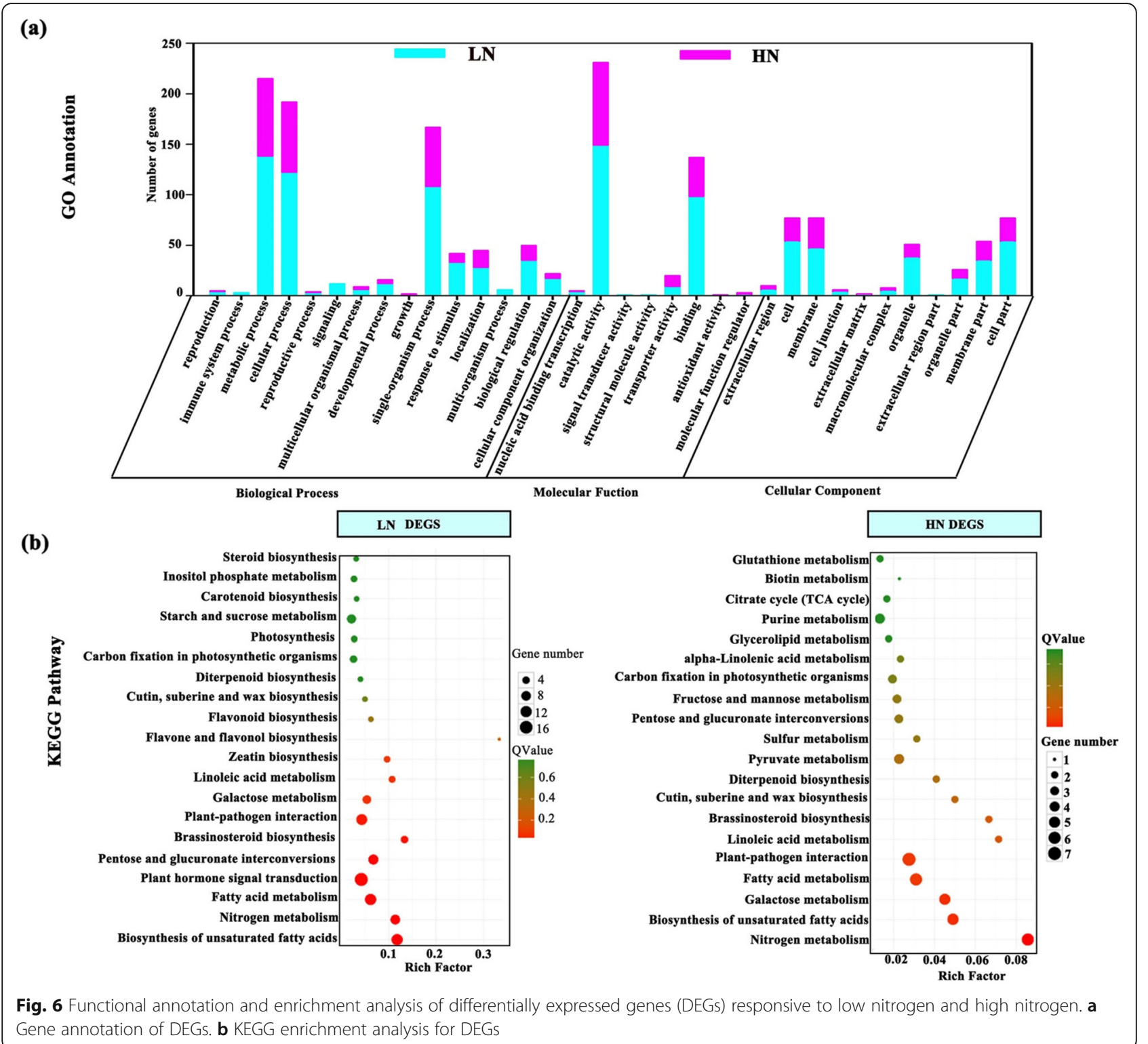

Real-time quantitative PCR (RT-qPCR) of photosyntheticrelated genes

In RT-qPCR analyses, melting curves of actin and 19 photosynthetic-related genes were clear and every curve all held a single and sharp peak (Additional file 9: Figure S8), indicating that the primer pairs could positively amplify specific products of 19 genes (Additional file 10: Table S2). The expressions of 19 genes were approximately similar to the results from RNA-Seq data in leaves (Additional file 11: Figure S9).

\section{Discussion}

$\mathrm{N}$-driven changes in photosynthesis is in part explained by leaf anatomy and $\mathrm{N}$ allocation

Photosynthetic capacity is at least in part determined by leaf anatomy and chloroplast ultrastructure [59] and $A_{\text {net }}$ is limited by the rate of $\mathrm{CO}_{2}$ diffusion from the atmosphere to the chloroplast [60]. $\mathrm{C}_{\text {lip }}$ has a close relationship with mesophyll cell thickness, and a thick tissue is always accompanied with a low $\mathrm{C}_{\text {lip }}$ [30]. Nevertheless, $\mathrm{C}_{\text {lip }}$ is positively related to the rate of $\mathrm{CO}_{2}$ diffusion from the atmosphere to the chloroplast [61]. $\mathrm{N}$ deficiency obviously reduce the size of chloroplasts and consequently lead to a low chloroplast surface area exposed to $S_{c}[16]$. Correspondingly, a large chloroplast has been documented in $\mathrm{HN}$-grown rice, and the large chloroplasts would enhance chloroplastic $\mathrm{CO}_{2}$ concentration $\left(\mathrm{C}_{\mathrm{c}}\right)$ and $g_{m}$ [62]. Thicker upper epidermis, lower epidermis, spongy tissue and palisade tissue (Table 1 ) would reduce liquid phase diffusion of $\mathrm{CO}_{2}$ in mesophyll cells, evidencing by lower $\mathrm{C}_{\text {lip }}$ in the $\mathrm{HN}$ individuals (Table 2), and 


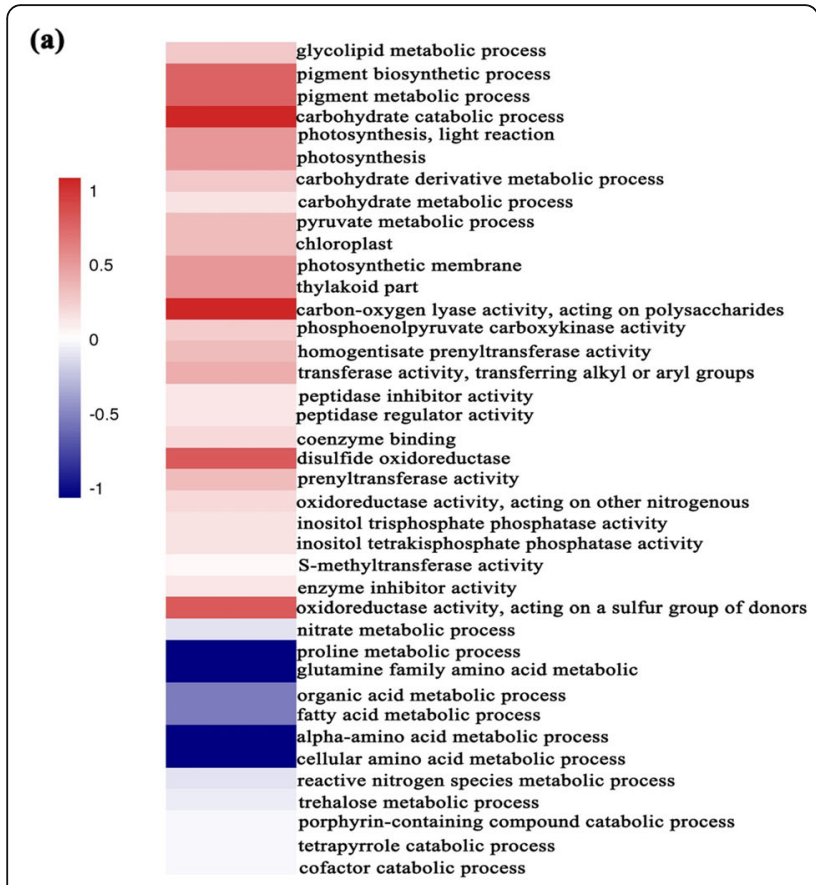

(b)

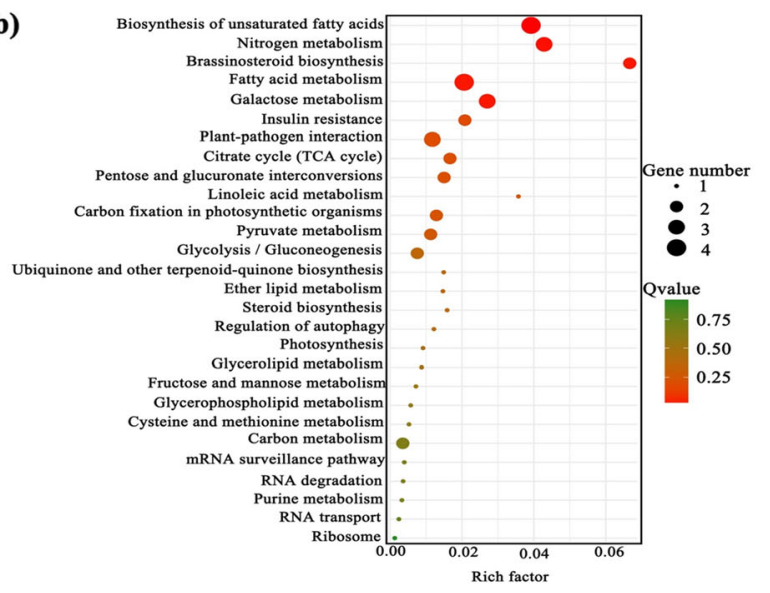

(c)

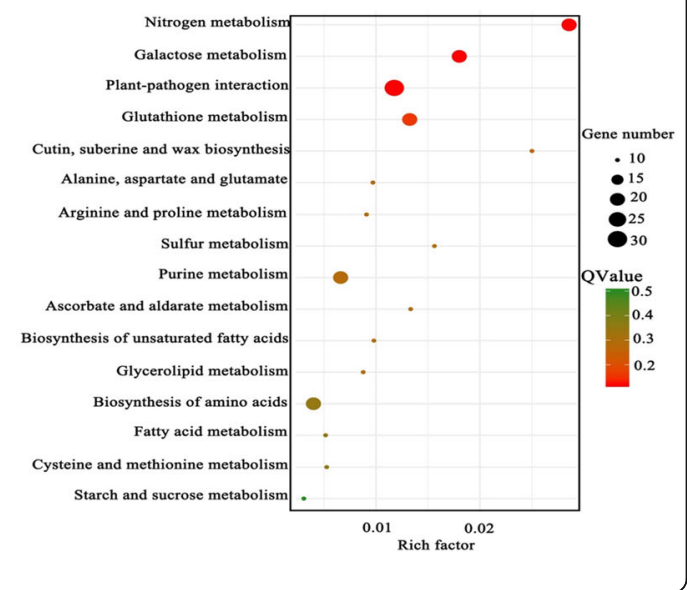

Fig. 7 Functional annotation and enrichment analysis of common differentially expressed genes (DEGs) between moderate- (MN) vs. low- (LN) nitrogen and high-nitrogen (HN) vs. LN comparisons. a Heat clustering of common DEGs based on the expression profiles. Blue indicates lower expression, and red indicates higher expression. b KEGG pathway analysis of up-regulated DEGs. (c) KEGG pathway analysis of down-regulated DEGs

this might partly explain the fact that a significant decrease in $A_{\text {net }}$ was observed in the HN individuals. The increase in size of chloroplast and in $g_{m}$ would contribute to the increase in $C_{\mathrm{c}}$ (Fig. $1 \mathrm{c}$; Table 2), as has also been observed in Tosens \& Laanisto [63]. $C_{\mathrm{c}}$ positively reinforce photosynthetic capacity [64-66]. Nevertheless, HN supply resulted in a decline in $A_{\text {net }}$ (Fig. 2), it has been thought that the increase in $g_{m}$ is not enough to provide sufficient $\mathrm{CO}_{2}$ to activate the increased Rubisco, the imbalance between $g_{m}$ and Rubisco content contributes to the reduction in $A_{\text {net }}$ in the $\mathrm{HN}$ individuals (Table 2) as has also been observed in Yin \& Struik [67]. LN-grown plants displayed small chloroplast and low $\mathrm{S}_{\mathrm{c}}$ (Fig. 1; Table 2) and these characteristics suppress $g_{\mathrm{i}}$ and $A_{\text {net }}$, as has been proposed by Onoda et al [68] .

$30-40 \%$ of leaf $\mathrm{N}$ is allocated to photosynthetic carboxylation and photosynthetic efficiency is determined by the proportion of $\mathrm{N}$ allocated to $\mathrm{N}_{\mathrm{C}}$ [69]. SLN is significantly increased, but $V_{\text {cmax }}, \mathrm{CE}$, Rubisco activity and $\mathrm{N}_{\mathrm{C}}$ is obviously decreased, and consequently photosynthetic efficiency is suppressed in wheat and rice grown in excessive $\mathrm{N}$ environment $[29,30]$. The $\mathrm{LN}$ plants exhibited lower SLN, Chl and $\mathrm{N}_{\mathrm{L}}$ (Tables 3, 4; Fig. 3 a), this would only limit the synthesis of light-trapping chlorophyll a/ b-protein complexes and effectively prevent absorption of excessive light energy [70]. Correspondingly, lower $\mathrm{N}_{\mathrm{C}}$ and activity of Rubisco were observed in the $\mathrm{HN}$ individuals (Fig. 3 a), this would suppress photosynthetic carboxylation and reduce photosynthetic efficiency.

\section{The dark and light reaction of photosynthesis under non- optimal $\mathrm{N}$ regimes}

Rubisco is the key $\mathrm{CO}_{2}$-fixing enzyme in Calvin cycle. The depressed photosynthesis in the LN plants might be the consequence of low Rubisco catalytic capacity and CE [30, 71]. Rubisco activity and CE were decreased in the $\mathrm{LN}$ individuals with down-regulated expression of genes encoding Rubisco (Tables 2, 3; Additional file 6: Figure S5). $\mathrm{N}$ deficiency in maize led to the decline in photosynthetic capacity and Rubisco catalytic capacity [22]. According to classic theories [72], $V_{\text {cmax }}$ positively reflects potential carboxylation capacity of Rubisco and regeneration rate of ribulose-bisphosphate (RuBP). $V_{\mathrm{cmax}}$ and Rubisco activity were considerably reduced in the $\mathrm{HN}$ individuals, whereas Rubisco content were increased (Tables 2,3). On the other hand, the expressions of 


\section{(a)}

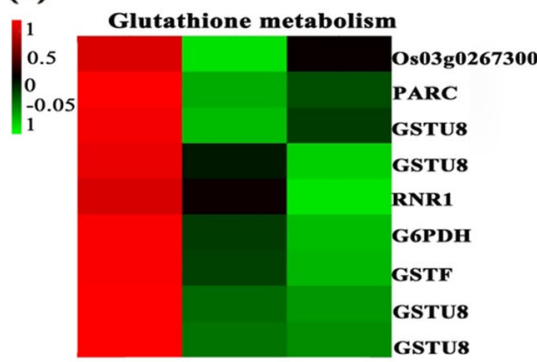

(c)

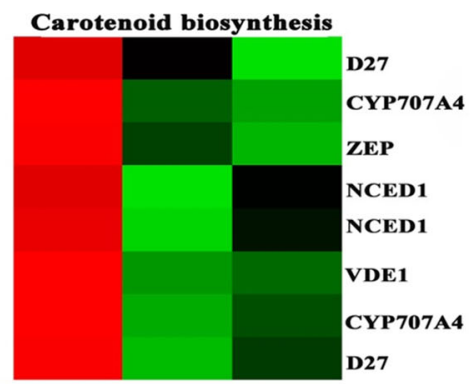

Porphyrin and chlorophyll metabolism

(e)

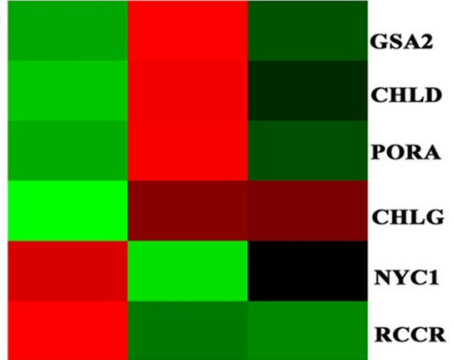

(g)

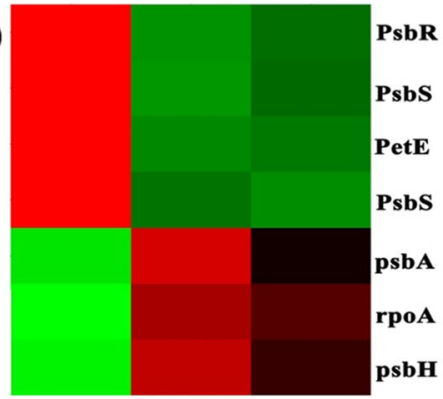

(i)

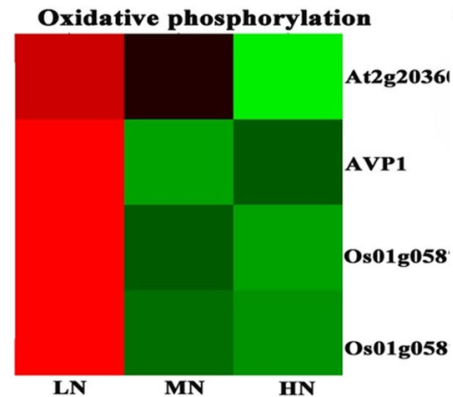

(b)

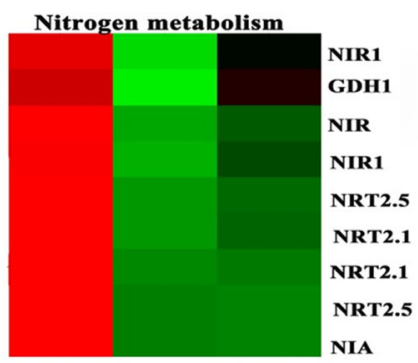

(d) Photosynthesis - antenna proteins

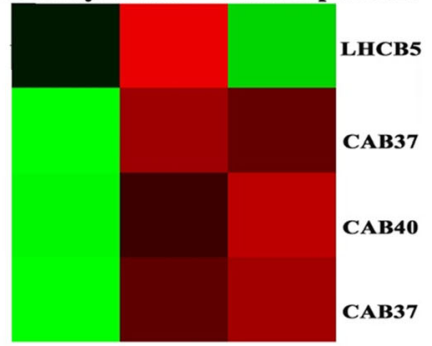

(f)
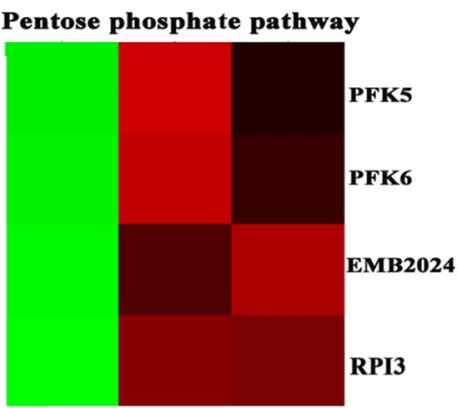

\section{Glycolysis/Gluconeogenesis}

(h)

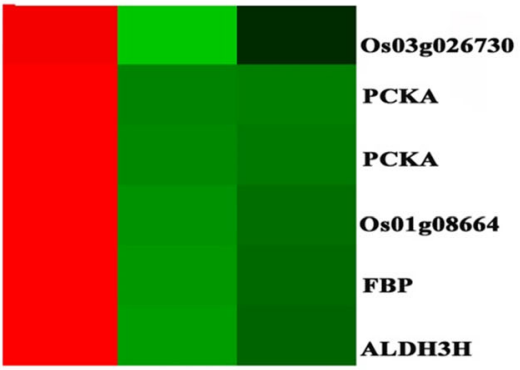

Carbon fixation in photosynthetic organisms

(j)

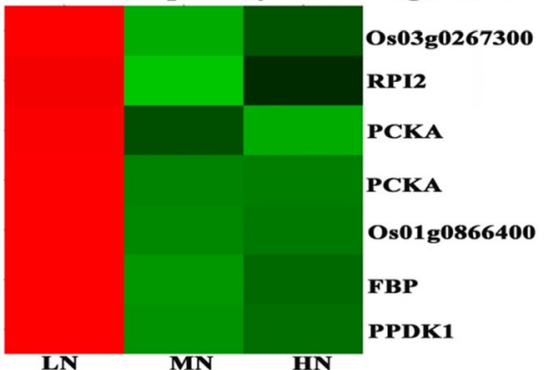

Fig. 8 Expression profiles of differentially expressed genes (DEGs) that regulate photosynthesis and photoprotection under different nitrogen level 
Rubisco-catalyzing genes (CPN60A1, Os02g079470025 and $R A F 2$ ) were down-regulated in the $\mathrm{HN}$ individuals (Tables 2, 3; Additional file 6: Figure S5). Overall, these results support the view that under $\mathrm{HN}$ supply, the majority of Rubisco function as $\mathrm{N}$ storage rather than as catalyzing enzyme [30], and the proportion of inactive Rubisco is greater in the HN leaves. However, high $\mathrm{Ru}-$ bisco activity is recorded in the HN-grown maize with high $A_{\max }$ [73]. The difference might be explained by the fact that $P$. notoginseng is a shade-tolerant $\mathrm{C} 3$ species and highly sensitive to excess $\mathrm{N}[54,55]$, and maize is a high $\mathrm{N}$ - and sun-demanding $\mathrm{C} 4$ plant $[74,75]$. In the atmospheric environment, Rubisco has a low affinity with $\mathrm{CO}_{2}$, resulting in inferior catalytic capacity [76]. The potential catalytic capacity of Rubisco in C3 plants is much lower than in C4 plants [77], suggesting that relatively less Rubisco operate on photosynthesis, and that a high proportion of Rubisco serves as a storage of $\mathrm{N}$ in $\mathrm{HN}$ grown $\mathrm{C} 3$ plants.

The expression of genes encoding enzymes involved in regeneration of RUBP was reduced in the LN individuals, including phosphor ribulokinase (PRK), phosphor glycerate kinase (PGK), glyceraldehyde-3phosphate dehydrogenase (GAPDH), triosephosphate isomerase (TPI), fructose-bisphosphate aldolase (FBA), transketolase (TKT) and sedoheptulose 1,7-bisphosphatase (SBP, Additional file 6: Figure S5), and correspondingly $A_{\text {net }}, \Phi_{\mathrm{PSII}}, F_{\mathrm{v}}{ }^{\prime} / F_{\mathrm{m}}{ }^{\prime}$ and $J_{\mathrm{T}}$ were reduced. Likewise, $\mathrm{N}$ deficiency suppress photosynthetic capacity and inhibit the expression of genes involved in dark reaction of photosynthesis in barley (Hordeum vulgare) [78] and rice [79]. Our findings are in general agreement with several previous researches that down-regulated expressions of genes encoding enzymes involved in the regeneration of Rubisco is associated with abiotic stress [80, 81].

Photosynthetic assimilation and photosynthetic electronic transport was considerably decreased in the LN and $\mathrm{HN}$ individuals (Figs. 2, 4; Additional file 3: Figure S3), and it is believed to derive from an interruptive synthesis of photosynthetic proteins [82]. The expression of genes encoding structural proteins of photosystems, including $P s b A, P s b E, P s b F, P s b H$ and PsaN, were decreased in the LN- and HN-grown individuals, while the expression of genes encoding subunits of the PsbS and PetE was increased as compared with the MN individuals (Additional file 7: Figure S6a). The expression of genes encoding structural proteins of photosystems are positively correlated with photosynthetic capacity [83, 84]. In addition, the down-regulation of genes involved in porphyrin and Chl metabolism and photosynthesis-antenna proteins might also in part explain the depressed photosynthetic capacity in the LN individuals (Fig. 8).

\section{Photoprotection in $\mathrm{N}$ deprivation}

Lower $A_{\max }, V_{\text {cmax }}$ and $J_{\max }$ were recorded in the $\mathrm{LN}$ and $\mathrm{HN}$ individuals when compared with the $\mathrm{MN}$ individuals (Table 3 ). No-optimal $\mathrm{N}$ application induces suppressions of photosynthesis as has been recorded in the sun-demanding species Viciafaba [85], Lemna minor [86], Z. mays [87] and C. sativus [48], and in the shadetolerant species Abies fabri [88], Brassica juncea [89] and polypodiopsida [90]. On the other hand, $\Phi_{\mathrm{PSII}}$ was lower in the LN individuals than in the HN individuals (Fig. 4 b), indicating that a greater proportion of light energy absorbed by PSII would have to be expended by non-photochemical process in the LN individuals. The consumption of electrons by non-photochemical process would facilitate the formation of trans-thylakoid $\Delta \mathrm{pH}$ [86]. $\triangle \mathrm{pH}$ is also a precondition for the activation of VAZ cycle and NPQ [91]. This indicates that NPQ and $\mathrm{V}$ cycle pool might be reinforced in the $\mathrm{LN}$ individuals as confirmed by the present study (Fig. 4 d; Table 4).

The degradation of Chl has been believed to be a photoprotective mechanism for plants to cope with stress and to prevent photodamage [92, 93]. Chl was considerably reduced in LN-grown plants (Table 4). Genes involved in Chl degradation were found to be enriched in LN-grown plants, and genes encoding NYC and $R C C R$ were up-regulated (Additional file 8: Figure S7c). The results obtained in our study indicate that low $\mathrm{Chl}$ in LN-grown plants might be caused by up-regulation of genes involved in Chl degradation. Similarly, the expression of genes involved in Chl degradation are also elevated in a shade-tolerant plant Neoregelia cruenta when grown under N-limited condition, together with the obvious decrease in leaf Chl [40]. LN-grown Spinach showed low $\mathrm{Chl}$ content and the corresponding elevation in expression of genes involved Chl degradation [94, 95].

Car is not comprised of $\mathrm{N}$ atoms and their accumulation is beneficial for protecting photosystem from photodamage $[42,96]$. The genes involved in Car biosynthesis (GGPS, DXR, PSY, IPI and DXS) were down-regulated in the $\mathrm{HN}$ individuals (Additional file 8: Figure S7e), as has also been observed by Vidhyavathi et al [97]. Correspondingly, the expression of genes involved in Car biosynthesis were up-regulated in Haematococcus pluvialis by a combination of light and N-deprivation [98]. Further, a greater xanthophyll pool size $(\mathrm{V}+\mathrm{A}+\mathrm{Z})$ and higher deepoxidation state $((\mathrm{A}+\mathrm{Z}) /(\mathrm{V}+\mathrm{A}+\mathrm{Z}))$ were observed in the LN individuals (Table 4), this suggests that LN cloud effectively improve the capacity of heat dissipation. The $P s b S$ protein and violaxanthin de-epoxidase is believed to involve in regulating energy dissipation [93]. The latter catalyses the de-epoxidation of $\mathrm{V}$ to $\mathrm{Z}$ [99]. $\Delta \mathrm{pH}$-dependent quenching (qE) is activated by $P s b S$ and the xanthophyll cycle [100]. The expression of genes encoding ZEP and VDE (key enzymes in xanthophyll cycle) were up- 
regulated in the LN individuals with the enhanced expression of PsbS genes (Additional file 8: Figure S7a), as has been observed in $\mathrm{LN}$-induced maize where genes involved de-epoxidation state were up-regulated [34].

Nitrate assimilation is a process highly sensitive to $\mathrm{N}$ stresses [101]. Nitrite assimilation consumes six electrons from reduced ferredoxin [102, 103]. This reaction is a strong alternative sink for photosynthetic electron transport chain. The expressions of genes encoding nitrite reductase $(N I R)$ and nitrate reductase $(N I A)$ were increased in the LN-grown individuals (Additional file 8: Figure S7d). It has been reported that maize [74], $A$. thaliana [104] and apple [105] show high activity of NIR and NIA in leaves in presence of suboptimal N application. The previous investigations and the present study both strongly evidence that $\mathrm{LN}$-induced enhancement in nitrate assimilation might mitigate the accumulation of excess energy.

\section{Conclusion}

The non-optimal $\mathrm{N}$ supply significantly suppresses photosynthetic capacity in a typically shade-tolerant and $\mathrm{N}$-sensitive species such as $P$. notoginseng. Thick leaf limits liquid phase diffusion of $\mathrm{CO}_{2}$ in mesophyll cells and accordingly reduces internal conductance. Moreover, large chloroplast with low $\mathrm{N}_{\mathrm{c}}$ results in an imbalance between the increases in gm and in Rubisco content, consequently causing the decreased $A_{\text {net }}$ in the $\mathrm{HN}$ individuals. In addition, the expression of genes involved in Calvin cycle, Chl biosynthesis and antenna proteins are obviously repressed in the LN individuals; correspondingly, the expression of genes (e.g. RAF2, $C A B$ and PetE) involved in Calvin cycle and light reaction is also inhibited, however, photosynthetic capacity might be primarily inhibited by the inactivated Rubisco in the $\mathrm{HN}$ individuals. Overall, our results indicate that photosynthetic performance and photosynthesis-related genes expression is coordinated in a shade-tolerant and $\mathrm{N}$-sensitive plant grown along an $\mathrm{N}$ gradient.

\section{Methods}

\section{Plant materials and growth conditions}

Experimental plots were conducted at the teaching and experimental farm of Yunnan Agricultural University in Kunming, Yunnan, China. P. notoginseng is a perennial herb; farmers have cultivated this medicinal crop for more than 400 years. One-year-old $P$. notoginseng seedlings were collected from the Wenshan Miao Xiang P. notoginseng Industrial Co., Ltd., China (Longitude $104^{\circ} 32^{\prime}$ ', latitude $23^{\circ} 53$ '). 1-year-old healthy rootstalks of $P$. notoginseng were selected in our experiments and transplanted to a white plastic pot $(30 \mathrm{~cm}$ in diameter and $40 \mathrm{~cm}$ in depth) on January 2017, and 3 individuals per pot, 120 pots per treatment were arranged.
The soil had the following chemical characteristics: organic mater $0.573 \%$, total $\mathrm{N} 0.201 \%, \mathrm{pH}\left(\mathrm{H}_{2} \mathrm{O}\right) 6.42$, total phosphorus (P) $0.727 \mathrm{~g} / \mathrm{kg}$, ammonium N $39.93 \mathrm{mg} / \mathrm{kg}$, available potassium (K) $0.019 \mathrm{mg} / \mathrm{g}$, available P $4.88 \mathrm{mg} /$ $\mathrm{kg}$, soil water regime $12 \%$. Pots were placed in environmentally controlled growth permeable black plastic net with growth irradiance of $10 \%$ full sunlight. Three Nfertilizer levels were applied in our experiments: (1) LN without $\mathrm{N}$ addition, (2) MN with $225 \mathrm{~kg} \cdot \mathrm{ha}^{-1} \mathrm{~N}$ addition in four applications, (3) $\mathrm{HN}$ with $450 \mathrm{~kg} \cdot \mathrm{ha}^{-1} \mathrm{~N}$ addition in four applications. $\mathrm{N}$ was supplied on April 22, June 22, July 22, August 22, 2017 respectively, along with 225 $\mathrm{P}_{2} \mathrm{O}_{5} \mathrm{~kg} \cdot \mathrm{ha}^{-1}$ (superphosphate) and $450 \mathrm{~kg} \cdot \mathrm{ha}^{-1} \mathrm{~K}_{2} \mathrm{O}$ (potassium sulphate) in four applications.

$P$. notoginseng grown for 8 months were used to determine plant mortality, leaf morphology and photosynthetic performance, and to collect leaves for comparative transcritome, chlorophyll and elemental $\mathrm{N}$ analyses. Five biological replicates were quickly frozen in liquid $\mathrm{N}$ and stored at $-80^{\circ} \mathrm{C}$ for RNA extraction.

\section{Leaf anatomy and chloroplast ultrastructure}

The juvenile leaves achieved for morphological and anatomical traits were used after 8 months of the $\mathrm{N}$ regimes. Leaf anatomical properties were performed in the method of paraffin section, and then the leaves were dehydrated in an alcohol series. Leaf tissues were embedded in paraffin (Thermo Scientific Histostar ${ }^{\mathrm{rm}}$ ) and transversely sectioned at $10 \mathrm{~mm}$ thickness by means of microtome (Microm HM325, Walldorf, Germany). Finally, sections were stained with hematoxylin observed under a bright field Microscope (Zeiss Axio Cam HRC, Oberkochen, Germany).

A small piece of $1 \sim 2 \mathrm{~mm}^{2}$ was cut between the middle leaf vein and leaf edge and fixed with $2.5 \%$ glutaraldehyde and $1 \%$ osmic acid. According to the conventional series of ethanol dehydration, epoxy resin embedding, ultra-thin slicer sectioning, sectioning was stained with uranyl acetate and then stained with lead citrate, the chloroplast ultrastructure was observed under JEM100CX-II transmission electron microscope. For the estimation of Sc, $700 \mathrm{~nm}$-thick sections were used by the method of Hanba et al [59].

\section{Steady-state gas exchange rate}

Steady-state gas exchange measurements were carried out using the photosynthesis system (Li-6400-40, Li-Cor, USA) with the $2 \mathrm{~cm}^{2}$ fluorescence leaf chamber. The leaf temperature and $\mathrm{CO}_{2}$ in the chamber were maintained at $25^{\circ} \mathrm{C}$ and $400 \mu \mathrm{mol} \mathrm{mol}^{-1}$ during measurements, respectively. Subsequently, Photosynthetic light response curves and photosynthetic $\mathrm{CO}_{2}$ response curves were performed. Based on photosynthetic light response curves, full induction was complete, an automatic 
program of light response curves was run to measure the change in gas exchange rate with a set of PPFD. The level of PPFD was listed in the following order: 800, 500, 400, 300, 200, 100, 80, 60, 40, 20 and $0 \mu \mathrm{mol} \mathrm{m}^{-2} \mathrm{~s}^{-1}$, each light intensity stabilized for $5 \mathrm{~min}$. The relationship between $A_{\text {net }}$ and PPFD was fitted, $A_{\text {net }}=A_{\max }-A_{\text {max }}$ $\mathrm{C}_{0} \mathrm{e}^{-\alpha P P F D} / A \max$, where $A_{\max }$ is the maximum net photosynthetic assimilation under saturating light, $\alpha$ is the apparent quantum efficiency (AQY), where AQY was estimated by the slope of the linear region of the light response curve. $C_{0}$ is the index to measure the net photosynthetic rate approaching 0 in low light. According to the parameters in the formula, dark respiration rate $\left(R_{\mathrm{d}}\right)=A_{\text {max }}-A_{\max } \mathrm{C}_{0}$.

$A_{\text {net }}$ and $C_{\mathrm{i}}$ were evaluated at a range of reference $\mathrm{CO}_{2}$ concentrations $(400,300,200,150,100,50,400,600$, 800,1000 and $\left.12001500 \mu \mathrm{mol} \mathrm{mol}^{-1}\right) . \mathrm{CO}_{2}$ response curves and $\mathrm{CE}$ were achieved by fitting the data to a nonrectangular hyperbola and the slope the linear region of the $\mathrm{CO}_{2}$ response curve, respectively. $V_{\text {cmax }}$ and $J_{\max }$ was gained according to the idea offered by Buckley and Diazespejo [106], this calibration requires measurements under low $\mathrm{O}_{2}$.

\section{Chlorophyll fluorescence of PSII}

At predawn, minimum and maximum $\mathrm{Chl}$ fluorescence yield $\left(F_{\mathrm{O}}\right.$ and $\left.F_{\mathrm{m}}\right)$ was measured in the fully darkadapted leaves. Minimum, maximum and steady-state fluorescence intensity $\left(F_{\mathrm{O}}{ }^{\prime}, F_{\mathrm{V}}{ }^{\prime}, F_{\mathrm{m}}{ }^{\prime}\right.$ and $\left.F_{\mathrm{s}}\right)$ were made in the process of light response curves. $F_{\mathrm{v}} / F_{\mathrm{m}}$ ' was estimated as $\left(F_{\mathrm{m}}{ }^{\prime}-F_{\mathrm{O}}{ }^{\prime}\right) / F_{\mathrm{m}}{ }^{\prime} ; \Phi_{\mathrm{PSII}}$ as $\left(F_{\mathrm{m}}{ }^{\prime}-F_{\mathrm{s}}\right) / F_{\mathrm{m}}{ }^{\prime} ; J_{\mathrm{T}}=$ $\mathrm{PPFD} \times \Phi_{\mathrm{PSII}} \times \alpha_{\text {leaf }} \times \beta$, commercial fluorometers usually provide an estimate of PSII total electron transport rate $\left(J_{\mathrm{T}}\right)$ by assuming that $400-700 \mathrm{~nm}$ (PAR) leaf absorptance $\left(\alpha_{\text {leaf }}\right)$ equals 0.84 [107] and that absorbed photons $(\beta)$ are equally distributed between the two photosystems $(\beta=0.5)$ [108]. This approximation is reasonable for comparison of $J_{\mathrm{T}}$ between optically similar samples such as leaves of cultivars of a single plant species [109]. Moreover, there was a curvilinear relationship between $\alpha_{\text {leaf }}$ and chlorophyll content, whereas the curvature was extremely low when the chlorophyll content was $>0.4$ $\mathrm{mmol} \mathrm{m}^{-2}[30,110]$. According to Evans and Poorter [110], the calculation of $\alpha_{\text {leaf }}$ demonstrated that $\alpha_{\text {leaf }}$ $(0.84,0.85$, and 0.85 , in leaves with low, moderate, and high $\mathrm{N}$ content, respectively) was similar to the value of 0.84 [111-113]. Therefore, in this study, $\alpha_{\text {leaf }}$ also assumed to be 0.84 , and $\beta$ was assumed to be $0.5[108$, 114]. NPQ as $\left(F_{\mathrm{m}}-F_{\mathrm{m}}{ }^{\prime}\right) / F_{\mathrm{m}}{ }^{\prime}$, and $\mathrm{qP}$ as $\left(F_{\mathrm{m}}{ }^{\prime}-F_{\mathrm{s}}\right) /\left(F_{\mathrm{m}}{ }^{\prime}\right.$ $\left.-F_{0}{ }^{\prime}\right){ } J_{\mathrm{C}}$ and $J_{\mathrm{O}}$ was calculated according to the method of Valentini et al [115], $J_{O}=2 / 3 \times\left(J_{T}-4 \times\left(A_{\text {net }}+R_{\mathrm{d}}\right)\right)$, $J_{C}=1 / 3 \times\left(J_{T}+8 \times\left(A_{\text {net }}+R_{\mathrm{d}}\right)\right)$. According to the methods of Manter and Kerrigan [116], $g_{\mathrm{m}}$ and $C_{\text {lip }}$ were calculated as $\mathrm{g}_{\mathrm{m}}=A_{\text {net }} /\left\{C_{\mathrm{i}} \Gamma^{* *} \times\left[U_{\mathrm{T}}+8\left(A_{\text {net }}+R_{\mathrm{d}}\right)\right] /\left[U_{\mathrm{T}^{-}}\right.\right.$
$\left.\left.4\left(A_{\text {net }}+R_{\mathrm{d}}\right)\right]\right\}, \quad \mathrm{C}_{\text {lip }}=\Gamma^{*} \times\left[U_{\mathrm{T}}+8\left(A_{\text {net }}+R_{\mathrm{d}}\right)\right] /\left[J_{\mathrm{T}}-\right.$ $\left.4\left(A_{\text {net }}+R_{\mathrm{d}}\right)\right]$, where $\Gamma^{*}$ is the $\mathrm{CO}_{2}$ compensation point. $C_{c}$ was calculated as $C_{c}=C_{i} \times S * / S$. The initial slope of the regression of $J \mathrm{c} / J_{0}$ to $\mathrm{C}_{\mathrm{i}} / \mathrm{O}$ was used to $\mathrm{S}$ (Additional file 12: Figure $\mathrm{S} 10), \mathrm{O}_{2}$ concentration $(210 \mathrm{mmol}$ $\left.\mathrm{CO}_{2} \mathrm{~mol}^{-1}\right)$. S was calculated as follow: $\mathrm{S}=\mathrm{O} / 2 \Gamma^{*}$. g glip can be showed that $\mathrm{g}_{\text {lip }}=\mathrm{C}_{\text {lip }} \times \mathrm{S}_{\mathrm{c}} \cdot \mathrm{g}_{\mathrm{i}}$ was calculated by $\mathrm{g}_{\mathrm{i}}=A_{\max } /\left(\mathrm{C}_{\mathrm{i}}-\mathrm{C}_{\mathrm{c}}\right)$.

Calculation of $\mathrm{N}$ allocation in photosynthetic components Leaf $\mathrm{N}$ was determined with Kjeldahl. SLN was calculated. Photosynthetic-related pigments were determined by the method of $\mathrm{Xu}$ et al. [91] and Thayer \& Björkman [117]. $N_{C}, N_{B}$ and $N_{L}$ were determined according to the method of Niinemets et al [118]. $\mathrm{N}_{\text {photo }}$ is the sum of $\mathrm{N}_{C}, \mathrm{~N}_{\mathrm{B}}$ and $\mathrm{N}_{\mathrm{L}}$. PNUE is the ratio of leaf $\mathrm{N}$ used for $\mathrm{C}$ fixation per unit leaf area. The formula is as follows:

$$
\begin{aligned}
& \mathrm{N}_{\mathrm{C}}=\left[V_{\mathrm{cmax}} /\left(6.25 \times \mathrm{V}_{\mathrm{cr}} \times \mathrm{SLN}\right)\right] \times \mathrm{SLN} \\
& \mathrm{N}_{\mathrm{B}}=\left[J_{\max } /\left(8.06 \times J_{\mathrm{mc}} \times \mathrm{SLN}\right)\right] \times \mathrm{SLN} \\
& \mathrm{N}_{\mathrm{L}}=\left[\mathrm{Cc} /\left(C_{\mathrm{B}} \times \mathrm{SLN}\right)\right] \times \mathrm{SLN} \\
& \mathrm{N}_{\text {photo }}=\mathrm{N}_{\mathrm{C}}+\mathrm{N}_{\mathrm{B}}+\mathrm{N}_{\mathrm{L}} \\
& \text { PNUE }=A_{\mathrm{mPNUE}=A_{\max } / \mathrm{SLNax}} / \mathrm{SLN}
\end{aligned}
$$

$\mathrm{V}_{\mathrm{cr}}$ is the Rubisco specific activity with a value of $20.8 \mu \mathrm{mol} \mathrm{CO}_{2} \cdot \mathrm{g}^{-1}$ Rubisco $\cdot \mathrm{s}^{-1}$. $J_{\mathrm{mc}}$ is the maximum electron transfer rate per unit cytochrome $f($ Cyt $f$ ) with a value of $155.6 \mu \mathrm{mol}$ electrons. $\mu \mathrm{mol}-1 \mathrm{Cyt} \mathrm{f \cdot s^{-1 }}$. Cc is the leaf chlorophyll content $\left(\mathrm{mmol} \cdot \mathrm{m}^{-}{ }^{2}\right), \mathrm{C}_{\mathrm{B}}$ is the combined light system I (PSI), photosystem II (the chlorophyll in PSII) and PSII light-harvesting pigment complex (LHCII) with a value of $2.15 \mathrm{mmol} \cdot \mathrm{g}^{-1} \mathrm{~N}$.

\section{Leaf Rubisco content and activity}

The Rubisco content was determined according to Makino et al [119]. Briefly, newly expanded leaves were stored at $-80^{\circ} \mathrm{C} .0 .5 \mathrm{~g}$ frozen leaves were ground in a solution containing $50 \mathrm{mM}$ Tris- $\mathrm{HCl}(\mathrm{pH}=8.0), 5 \mathrm{mM}$ $\beta$-mercaptoethanol, and $12.5 \%$ glycerol $(\mathrm{v} / \mathrm{v})$, and then centrifuged at $1500 \mathrm{~g}$ for $15 \mathrm{~min}$ at $4{ }^{\circ} \mathrm{C}$. The supernatants were mixed with a solution containing $2 \%(\mathrm{w} / \mathrm{v})$ SDS, $4 \%(\mathrm{v} / \mathrm{v}) \beta$-mercaptoethanol and $10 \%$ (v/v) glycerol, boiled in a water bath for $5 \mathrm{~min}$ before SDS-PAGE using a $4 \%(\mathrm{w} / \mathrm{v})$ stacking gel, and a $12.5 \%(\mathrm{w} / \mathrm{v})$ separating gel. After electrophoresis, the gels were stained with $0.25 \%$ Commassie Blue for $12 \mathrm{~h}$, and destained. Gel slices containing the large subunits and small subunits of Rubisco were transferred to a $10 \mathrm{~mL}$ cuvette containing $2 \mathrm{ml}$ of formamide and incubated at $50^{\circ} \mathrm{C}$ in a water bath for $6 \mathrm{~h}$. The absorbance of the wash solution was measured at $595 \mathrm{~nm}$. Protein concentrations were determined using bovine serum albumin as a standard. 
Bovine serum albumin (BSA) was measured at $595 \mathrm{~nm}$ as standard protein.

Rubisco activity was measured according to Parry et al [120] with minor modifications. The extraction solution contained: $50 \mathrm{mM}$ Tris- $\mathrm{HCl} \quad(\mathrm{pH}=7.5), \quad 10 \mathrm{mM} \quad \beta$ mercaptoethanol, 12.5\% (v/v) glycerol, $1 \mathrm{mM}$ EDTA$\mathrm{Na}_{2}, 10 \mathrm{mM} \mathrm{MgCl}$ and $1 \%(\mathrm{~m} / \mathrm{v})$ PVP-40. Extracts were clarified by centrifugation $\left(8000 \mathrm{~g}\right.$ at $4{ }^{\circ} \mathrm{C}$ for $10 \mathrm{~min}$ ) and the supernatant was immediately assayed for $\mathrm{Ru}$ bisco activity.

\section{RNA extraction and library construction, sequencing}

RNA samples were extracted using RNA pre-pure Plant Kit (Tiangen, Beijing, China). After total RNA was extracted, mRNA was enriched by Oligo (dT) bads, and then the enriched mRNA was fragmented into short fragments using fragmentation buffer and reverse transcripted into cDNA with random primers. Secondstrand cDNA were synthesized by DNA polymerase I, RNase $\mathrm{H}, \mathrm{dNTP}$ and buffer. The cDNA fragments were purified with QiaQuick PCR extraction kit, end repaired, poly(A) added, and ligated to Illumina sequencing adapters. The ligation products were selected by agarose gel electrophoresis, PCR amplified, and sequenced using Illumina HiSeqTM 4000 by Gene Denovo Biotechnology Co. (Guangzhou, China).

\section{Raw reads filtering and de novo assembly}

Low quality reads containing adapters, more than $10 \%$ of unknown nucleotides $(\mathrm{N})$, were eliminated. Transcriptome de novo assembly was carried out with short reads assembling program-Trinity. The redundancy was eliminated by the TGICL software and further assembled into a set of non-redundant unigenes.

105G sequencing data were obtained and de novo assembled into 93,162 unigenes (Additional file 13: Table S3) with an average length of $790 \mathrm{bp}$ (Additional file 14: Table S4). Collectively, 41,569 (44.62\%) unigenes were functionally annotated in accordance with their parallels with known genes/proteins in the databases. The particular statistics of the functional annotation are emerged as in Additional file 15: Figure S11. After eliminating adaptors, unknown nucleotides and low quality reads, the data generated 43,588,606, 46,978,940, 43,177, 242 paired-end 125 -bP reads in the $\mathrm{LN}, \mathrm{MN}$ and $\mathrm{HN}$ treatments, respectively, coinciding with approximately $6.48 \mathrm{~Gb}$ data (Additional file 16: Table S5). Q20 percentages exceeded $98 \%$, uncalled base ("N") percentage was equal to $0 \%$ per sample (Additional file 16: Table S5). The GC contents were almost identical for all 15 leaves tissues, ranging from 43.08 to $44.20 \%$ (Additional file 16: Table S5). In general, between 83.23 and $84.79 \%$ of clean reads could be mapped on full gene set (Additional file 17: Table S6). A Pearson's correlation analysis revealed high correlations between biological replicates $\left(R^{2}=0.8671\right.$ to 0.9769, Additional file 18: Figure S12).

\section{Basic annotation of unigenes}

To annotate the unigenes, we used BLASTx program (http://www.ncbi.nlm.nih.gov/BLAST/) with an E-value threshold of $1 \mathrm{e}^{-5}$ to NCBI non-redundant protein $(\mathrm{Nr})$ database (http://www.ncbi.nlm.nih.gov), the Swiss-Prot protein database (http://www.expasy.ch/sprot), the Kyoto Encyclopedia of Genes and Genomes (KEGG) database (http://www.genome.jp/kegg), and the COG/KOG database (http://www.ncbi.nlm.nih.gov/COG). Protein functional annotations are obtained according to the best alignment results.

\section{Analysis of DEGs}

To identify DEGs within $\mathrm{N}$ regimes, the normalized read counts from five replicates of each sample were analyzed and the edge $\mathrm{R}$ package (http://www.r-project.org) was used. We identified genes with a fold change $\geq 2$ and a false discovery rate (FDR) $<0.05$ in a comparison as significant DEGs. DEGs were then subjected to enrichment analysis of GO functions and KEGG pathways.

\section{GO enrichment analysis and pathway enrichment analysis} All DEGs were mapped to GO terms in the Gene Ontology database (http://www.geneontology.org), gene numbers were calculated for each term, significantly enriched GO terms in DEGs comparing to genome background were defined by hyper geometric test. KEGG enrichment analysis was carried out through Genomes database (g" http://www.genome.jp/kegg). P-value of GO terms and KEGG pathway was gone through FDR Correction, taking FDR $\leq 0.05$ as a threshold.

\section{RT-qPCR assay}

To validate the expression of 19 significant DEGs observed in RNA-Seq data, reaction was carried out using EvaGreen 2X qPCR MasterMix Kit (abm, Vancouver, Canada) in a Quanstudio 5 Real-Time PCR Intruments (Thermo Fisher Scientific, Inc.). First-strand cDNA was synthesized using the RevertAid ${ }^{\text {tw }}$ First strand cDNA Synthesis Kit (TransGen Biotech, Beijing, China). DEGs primers were designed using the Primer-Blast (/" https:// www.ncbi.nlm.nih.gov/tools/primer-blast/) and synthesized commercially (Shuoqing, Kunming, China). Actin were selected as reference genes [121]. The primers used in GRT-PCR analyses are listed in Table S1. Amplification reaction mixtures were made of $10 \mu \mathrm{L}$ of Eva Green 2X qPCR Master Mix, $0.5 \mu \mathrm{L}$ of each forward and reverse primer $(10 \mathrm{mM})$, and $1 \mu \mathrm{L}$ of $\mathrm{cDNA}$ template, and $\mathrm{ddH}_{2} \mathrm{O}$ was added to a final volume of $20 \mu \mathrm{L}$. The amplification cycling program was as follows: enzyme activation was operated at $95^{\circ} \mathrm{C}$ for 10 mins, moreover, 40 
cycles of $95^{\circ} \mathrm{C}$ for $15 \mathrm{~s}, 58^{\circ} \mathrm{C}$ for $30 \mathrm{~s}$ and $72{ }^{\circ} \mathrm{C}$ for $30 \mathrm{~s}$. The results were analyzed using the software accompanying the Quanstudio ${ }^{\text {Tn }} 5$ Real-Time PCR instruments. The relative expression values were obtained by using the $2^{-\Delta \Delta C t}$ method [122].

\section{Statistical analyses}

Statistical analyses were performed with SPSS software package (Chicago, IL, USA) and SigmaPlot 10.0, where the data were tested to confirm their normality and the variables were present as the mean $\pm \mathrm{SD}(n=5-7)$. We obtained 7 repetiotions that studied physiological parameter for $\mathrm{N}$ - cultivated plants, and we generally obtained 5 repetions for bioinformatic analyse. Differences were considered significant when $P<0.05$ according to the ANOVA F-test. The $\mathrm{Ct}$ values derived from qPCR were normalized and the relative fold changes in transcripts were calculated using the relative expression software tool, REST.

\section{Supplementary information}

Supplementary information accompanies this paper at https://doi.org/10. 1186/s12870-020-02434-z.

Additional file 1: Figure S1. Leaf phenotypic traits (a) and plant mortality (b) of Panax. notoginseng under nitrogen regimes.

Additional file 2: Figure S2. Detection of Rubisco large and small subunits in the leaves of Panax notoginseng.

Additional file 3: Figure S3. Responses of PSII total electron transport rate $\left(J_{T}, \mathbf{a}\right)$, rate of electron transport for oxidation reaction $\left(J_{O}, \mathbf{b}\right)$ and carboxylation reaction $\left(J_{C}, \mathbf{c}\right)$ to photosynthetic photon flux density (PPFD) in Panax notoginseng grown under different levels of nitrogen. Values for each point were means \pm SD $(n=7)$. Significant differences are indicated by asterisks (ANOVA; $P$ values $\leq 0.05$ ).

Additional file 4: Figure S4. Common differentially expressed genes (DEGs) and their expression profile between moderate- (MN) vs. low- (LN) nitrogen and MN vs. high-nitrogen (HN). Red number indicates uprelation, green number indicates down-relation.

Additional file 5: Table S1. KEGG enrichment analysis of the first 13 pathways related to the protective mechanism.

Additional file 6: Figure S5. Calvin cycle pathways of Panax notoginseng and hierarchical cluster analysis of genes that were differentially expressed under different nitrogen level. Red indicates that the gene has a high expression in the nitrogen level; green indicates that the gene has a lower expression in the nitrogen level.

Additional file 7: Figure S6. Differentially expressed genes (DEGs) participating in light reaction under varied nitrogen level. (a) MN vs LN and MN vs HN differential gene of photosynthesis pathway for samples of control group, the red box labeled for raising genes, green box labeled as the blue box labeled as there are raised and lowered genes at the same time, the box numbers for the number of the enzyme, suggests that the corresponding gene is associated with the enzyme, and the whole passage is there are many different forms through complex biochemical reactions, an enzyme that differences in genes associated with this pathway are marked by different color box. (b) The expression pattern of DEGs involved in photosynthesis pathway. Red indicates that the gene has a high expression in the nitrogen level; green indicates that the gene has a lower expression in the nitrogen level.

Additional file 8: Figure S7. The pathway and genes encoding for the photoprotection. In heat map, firebrick indicates that the gene has a high expression in the nitrogen level; navy indicates that the gene has a lower expression in the nitrogen level. (a) The expression pattern of DEGs involved in Lutein cycle. (b) The expression pattern of DEGs involved in Antioxidant pathway. (c) The expression pattern of DEGs involved in Chlorophyll degradation pathway. (d) The expression pattern of DEGs involved in nitrate assimilation. (e) The expression pattern of DEGs involved in Carotenoid metabolism.

Additional file 9: Figure S8. Melt curve of 19 differentially expressed genes (DEGs) and house-keeping gene (Actin).

Additional file 10: Table S2. Primers for the RT-qPCR assays of the twenty RNA-Seq libraries used in this study.

Additional file 11: Figure S9. Quantitative real-time PCR validation of 19 differentially expressed genes (DEGs) $(n=5)$. Data are mean with bars depicting standard deviation $( \pm S D)$. Significant differences are indicated by letters (ANOVA; $P$ values $\leq 0.05$ ). The columns represent relative expression obtained by RT-qPCR.

Additional file 12: Figure S10. The curvilinear relationships between $J_{C} / J_{0}$ and $C_{i} / O$. Every data point represents the mean value of five individual replicates, and small error bars indicate the standard deviation. Initial slopes of (a), (b), and (c) represent $\mathrm{S}^{*}$ of Panax notoginseng grown at low, moderate, and high $\mathrm{N}$ concentration, respectively.

Additional file 13: Table S3. De novo assembled genes of $P$. notoginseng grown under nitrogen regimes.

Additional file 14: Table S4. Assembly quality statics of $P$. notoginseng. Additional file 15: Figure S11. Statistics of the annotation of unigenes in public databases.

Additional file 16: Table S5. Summary of sequencing data quality for P. notoginseng.

Additional file 17: Table S6. Summary ofmapping rate and statistics of expression genes based on the RNA-Seq data.

Additional file 18: Figure S12. Pearson's correlation analysis of the RNA-Seq data.

\section{Abbreviations}

A: Antheraxanthin; $A_{\text {max: }}$ Maximum photosynthetic assimilation at the saturating light; At1g32060: Phosphoribulokinase; At1g43670: Fructose-1,6bisphosphatase; At1g56190: Phosphoglycerate kinase; At3g55800: Sedoheptulose-1,7-bisphosphatase; At4g26520: Fructosebisphosphate aldolase; ATPase: ATP synthase; CAB: Chlorophyll a/b binding protein; CAB13: Chlorophyll a/b binding protein 13; CAB37: Chlorophyll a/bbinding protein 1; CAB40: Chlorophyll a/b binding protein of LHCll type I precursor; $C_{c}$ : Chloroplastic $\mathrm{CO}_{2}$ concentration; $\mathrm{CE}$ : Carboxylation efficiency; $C_{i}$ : Internal leaf $\mathrm{CO}_{2}$ concentrations; $\mathrm{Clip}_{\text {lip }}$ : Conductance per unit of exposed chloroplast surface area; CPN60A1: Rubisco large subunit-binding protein subunit alpha; DEGs : Differentially expressed genes; FBA: Fructosebisphosphate aldolase; FBA3: Fructose-bisphosphate aldolase 1; FBP: Fructose-1,6-bisphosphatase; $F_{\mathrm{v}} / F_{\mathrm{m}}$ : Maximum quantum yield of photosystem II; G-6-P: Glucose 6-phosphate; G6PDH: Glucose-6-phosphatede hydrogenase; GAPC: Glyceraldehyde-3-phosphate dehydrogenase; GAPDH: Glyceraldehyde-3-phosphate dehydrogenase; GGPS: Geranyl pyrophosphate synthase; $g_{i}$ : Internal conductance; $g_{i}$ : Internal $\mathrm{CO}_{2}$ condutance; $g_{\text {lip: }}$ Liquid phase; $g_{m}$ : Mesophyll cell conductance; $g_{s}$ : Stomatal conductance; GSH: Oxidized glutathione; GSSG: Reduced glutathione; GSTF10: Glutathione S-transferase; GSTU8: Glutathione S-transferase; GTS: Glutathione S-transferase; HN : High nitrogen; IPI: Isopentenyl pyrophosphate isomerase; $J_{C}$ : Rate of electron transport for oxidation reaction; J max: Maximum electron transfer rate; $J_{O}$ : Carboxylation reaction; $J_{\text {T: }}$ PSII total electron transport rate; L: Lutein; LN : Low nitrogen; MN: Moderate nitrogen; N: Nitrogen; N: Neoxanthin; $\mathrm{N}_{B}$ : N allocation to bioenergetics component; $\mathrm{N}_{\mathrm{C}}$ : N allocation to the carboxylation system; NIA: Nitrate reductase; NIR: Nitrite reductase; NIR1: Nitrite reductase $1 ; N_{L}: N$ allocation to the light-harvesting system; $\mathrm{N}_{\text {photo: }} \mathrm{N}$ allocation to the photosynthetic system; NPQ : Non-photochemical quenching; NYC: Chlorophyll b reductase; Os01g0866400: Fructose-1,6-bisphosphatase;"; Os02g0794700: Rubisco accumulation factor 1; PGK: Phosphoglycerate kinase; PGK1: Phosphoglycerate kinase; PPFD: Photosynthetic photon flux density; PNUE: Photosynthetic nitrogen use efficiency; PRK: Phosphoribulokinase; PSY: Phytoene synthase; qP : Photochemical quenching; RAF2: Rubisco 
accumulation factor 2; RCCR: Red chlorophyll catabolite reductase; $R_{d}$ : Dark respiration rate; ROS: Reactive oxygen species; RPI: Ribose-5-phosphate isomerase; RPI2: Ribose-5-phosphate isomerase 2; RPI3: Ribose-5-phosphate isomerase 3; Rubisco: Ribulose 1, 5-bisphosphate carboxylase; SBP: Sedoheptulose 1,7-bisphosphatase; $S_{c}$ : Chloroplast exposed to intercellular air space per unit leaf area; SLN: Nitrogen content per unit leaf area; TKL-1: Transketolase; TKT: Transketolase; TPI: Triosephosphate isomerase; TPI: Triosephosphate isomerase; TPIP1: Triosephosphate isomerase; $V$ : Violaxanthin; $V_{\text {cmax: }}$ Maximum carboxylation efficienc; VDE1: Violaxanthinde-epoxidase; Z: Zeaxanthin; ZEP: Zeaxanthin epoxidase; $\Gamma^{*}$ : Carbon dioxide compensation point; $\alpha_{\text {leaf: }}$ Leaf absorptance; $\beta$ : : Absorbed photons; $\Phi_{\text {PSII: }}$ : Effective quantum yield of photosystem II; $\beta$-Car: $\beta$-Carotene

\section{Acknowledgements}

We thank Dr. GHZ for technical assistance. We are also grateful to HMW and $\mathrm{RMH}$ for their assistance with data analysis.

\section{Authors' contributions}

JWC conceived the study, JYZ designed the experiments and wrote the manuscript, ZC carried out the analysis. All authors have read and approved the current version of the manuscript.

\section{Funding}

This research was funded by the National Natural Science Foundation of China (No.81860676 \& No. 81360609) for material collection and RNA-seq, the Project of Young and Middle-Aged Talent of Yunnan Province (2014HB011) for determination of leaf anatomy and chloroplast ultrastructure and the Major Special Science and Technology Project of Yunnan Province (2016ZF001 \& 2017ZF001) for writing and publishing manuscript.

\section{Availability of data and materials}

All data generated or analyzed during this study are included in this published article and its supplementary information files.

\section{Ethics approval and consent to participate}

Not applicable. The authors declared that experimental research works on the plants described in this paper comply with institutional, national and international guidelines.

\section{Consent to publication}

Not applicable.

\section{Competing interests}

The authors declare that they have no competing interests.

\section{Author details}

${ }^{1}$ College of Agronomy \& Biotechnology, Yunnan Agricultural University, Kunming 650201, China. ${ }^{2}$ Key Laboratory of Medical Plant Biology of Yunnan Province, Yunnan Agricultural University, Kunming 650201, China. ${ }^{3}$ National \& Local Joint Engineering Research Center on Germplasm Innovation \& Utilization of Chinese Medicinal Materials in Southwestern China, Yunnan Agricultural University, Kunming 650201, China.

\section{Received: 1 November 2019 Accepted: 10 May 2020}

Published online: 28 June 2020

\section{References}

1. Crawford NM, Glass AD. Molecular and physiological aspects of nitrate uptake in plants. Trends Plant Sci. 1998;3(10):389-95.

2. Zhang X, Misra A, Nargund S, Coleman GD, Sriram G. Concurrent isotopeassisted metabolic flux analysis and transcriptome profiling reveal responses of poplar cells to altered nitrogen and carbon supply. Plant J. 2018;93(3): 472-88.

3. LeBauer DS, Treseder KK. Nitrogen limitation of net primary productivity in terrestrial ecosystems is globally distributed. Ecology. 2008;89(2):371-9.

4. Yin X, Schapendonk AH, Struik PC. Exploring the optimum nitrogen partitioning to predict the acclimation of C3 leaf photosynthesis to varying growth conditions. J Exp Bot. 2018;70(9):2435-47.

5. Tian Q, Chen F, Liu J, Zhang F, Mi G. Inhibition of maize root growth by high nitrate supply is correlated with reduced IAA levels in roots. J Plant Physiol. 2008;165(9):942-51.
6. Boussadia O, Steppe K, Zgallai H, El Hadj SB, Braham M, Lemeur R, Van Labeke M. Effects of nitrogen deficiency on leaf photosynthesis, carbohydrate status and biomass production in two olive cultivars 'Meski'and 'Koroneiki'. Sci Hortic-Amsterdam. 2010;123(3):336-42.

7. Massignam AM, Chapman SC, Hammer GL, Fukai S. Effects of nitrogen supply on canopy development of maize and sunflower. Crop Pasture Sci. 2012;62(12):1045-55

8. Gao K, Chen F, Yuan L, Zhang F, Mi G. A comprehensive analysis of root morphological changes and nitrogen allocation in maize in response to low nitrogen stress. Plant Cell Environ. 2015;38(4):740-50.

9. Wei S, Wang X, Shi D, Li Y, Zhang J, Liu P, Zhao B, Dong S. The mechanisms of low nitrogen induced weakened photosynthesis in summer maize (Zea mays L.) under field conditions. Plant Physiol Bioch. 2016;105:118-28.

10. Vos J, Van der Putten P. Effect of nitrogen supply on leaf growth, leaf nitrogen economy and photosynthetic capacity in potato. Field Crop Res. 1998:59(1):63-72.

11. Cechin I, de Fátima Fumis T. Effect of nitrogen supply on growth and photosynthesis of sunflower plants grown in the greenhouse. Plant Sci. 2004;166(5):1379-85

12. Eichelmann H, Oja V, Rasulov B, Padu E, Bichele I, Pettai H, Mänd P, Kull O, Laisk A. Adjustment of leaf photosynthesis to shade in a natural canopy: reallocation of nitrogen. Plant Cell Environ. 2005;28(3):389-401.

13. Yuan L, Yuan Y, Du J, Sun J, Guo S. Effects of 24-epibrassinolide on nitrogen metabolism in cucumber seedlings under $\mathrm{Ca}\left(\mathrm{NO}_{3}\right)_{2}$ stress. Plant Physiol. Bioch. 2012;61:29-35.

14. Zhang $\mathrm{G}$, Liu Z, Zhou J, Zhu Y. Effects of $\mathrm{Ca}\left(\mathrm{NO}_{3}\right)_{2}$ stress on oxidative damage, antioxidant enzymes activities and polyamine contents in roots of grafted and non-grafted tomato plants. Plant Growth Regul. 2008;56(1):7.

15. Cai Q, Ji C, Yan Z, Jiang X, Fang J. Anatomical responses of leaf and stem of Arabidopsis thaliana to nitrogen and phosphorus addition. J Plant Res. 2017; 130(6):1035-45.

16. Zhang $\mathrm{S}$, Jiang $H$, Zhao $H$, Korpelainen $H$, Li C. Sexually different physiological responses of Populus cathayana to nitrogen and phosphorus deficiencies. Tree Physiol. 2014;34(4):343-54

17. Liu Z, Gao J, Gao F, Liu P, Zhao B, Zhang J. Photosynthetic characteristics and chloroplast ultrastructure of summer maize response to different nitrogen supplies. Front Plant Sci. 2018;9:576.

18. Walcroft AS, Whitehead D, Silvester WB, Kelliher FM. The response of photosynthetic model parameters to temperature and nitrogen concentration in Pinus radiata D. Don. Plant Cell Environ. 1997;20(11): 1338-48.

19. Wang LY, Liu JL, Wang WX, Sun Y. Exogenous melatonin improves growth and photosynthetic capacity of cucumber under salinity-induced stress. Photosynthetica. 2016;54(1):19-27.

20. Bahar NH, Hayes L, Scafaro AP, Atkin OK, Evans JR. Mesophyll conductance does not contribute to greater photosynthetic rate per unit nitrogen in temperate compared with tropical evergreen wet-forest tree leaves. New Phytol. 2018;218(2):492-505.

21. Dubreuil C, Jin X, de Dios B-LJ, Hewitt TC, Tanz SK, Dobrenel T, Schröder WP, Hanson J, Pesquet E, Grönlund A. Establishment of photosynthesis through chloroplast development is controlled by two distinct regulatory phases. Plant Physiol. 2018;176(2):1199-214.

22. Lu C, Zhang J. Photosynthetic $\mathrm{CO}_{2}$ assimilation, chlorophyll fluorescence and photoinhibition as affected by nitrogen deficiency in maize plants. Plant Sci. 2000;151(2):135-43.

23. Pathan $\mathrm{SI}$, Ceccherini MT, Pietramellara G, Puschenreiter M, Giagnoni L Arenella M, Varanini Z, Nannpieri P, Renella G. Enzyme activity and microbial community structure in the rhizosphere of two maize lines differing in $\mathrm{N}$ use efficiency. Plant Soil. 2015;387(1-2):413-24.

24. Calzavara AK, Paiva P, Gabriel LC, Oliveira A, Milani K, Oliveira HC, Bianchin E, Pimenta JA, de Oliveira M, Dias PJ. Associative bacteria influence maize (Zea mays L.) growth, physiology and root anatomy under different nitrogen levels. Plant Biol. 2018;20(5):870-8.

25. Cai H, Lu Y, Xie W, Zhu T, Lian X. Transcriptome response to nitrogen starvation in rice. J Biosci. 2012:37(4):731-47.

26. Honoki R, Ono S, Oikawa A, Saito K, Masuda S. Significance of accumulation of the alarmone (p) ppGpp in chloroplasts for controlling photosynthesis and metabolite balance during nitrogen starvation in Arabidopsis. Photosynth Res. 2018:135(1-3):299-308.

27. Evans JR, Terashima I. Photosynthetic characteristics of spinach leaves grown with different nitrogen treatments. Plant Cell Physiol. 1988;29(1): $157-65$. 
28. Cruz JL, Mosquim PR, Pelacani CR, Araújo WL, DaMatta FM. Carbon partitioning and assimilation as affected by nitrogen deficiency in cassava. Photosynthetica. 2003;41(2):201-7.

29. Lopes MS, Araus JL. Nitrogen source and water regime effects on durum wheat photosynthesis and stable carbon and nitrogen isotope composition. Physiol Plantarum. 2006;126(3):435-45.

30. Li Y, Gao Y, Xu X, Shen Q, Guo S. Light-saturated photosynthetic rate in high-nitrogen rice (Oryza sativa L.) leaves is related to chloroplastic $\mathrm{CO}_{2}$ concentration. J Exp Bot. 2009;60(8):2351-60.

31. Yao $H$, Zhang $Y$, Yi X, Zhang $X$, Zhang W. Cotton responds to different plant population densities by adjusting specific leaf area to optimize canopy photosynthetic use efficiency of light and nitrogen. Field Crop Res. 2016;188:10-6.

32. Makino A, Osmond B. Effects of nitrogen nutrition on nitrogen partitioning between chloroplasts and mitochondria in pea and wheat. Plant Physiol. 1991;96(2):355-62

33. Rotundo $\mathrm{J}$, Cipriotti PA. Biological limits on nitrogen use for plant photosynthesis: a quantitative revision comparing cultivated and wild species. New Phytol. 2017;214(1):120-31.

34. Tóth VR, Mészáros I, Veres S, Nagy J. Effects of the available nitrogen on the photosynthetic activity and xanthophyll cycle pool of maize in field. J Plant Physiol. 2002;159(6):627-34

35. Correa-Galvis V, Poschmann G, Melzer M, Stühler K, Jahns P. PsbS interactions involved in the activation of energy dissipation in Arabidopsis. Nat Plants. 2016;2(2):15225

36. Cohen I, Rapaport T, Chalifa Caspi V, Rachmilevitch S. Synergistic effects of abiotic stresses in plants: a case study of nitrogen limitation and saturating light intensity in Arabidopsis thaliana. Physiol Plantarum. 2019;165(4):755-67.

37. Reis AR, Favarin JL, Gratão PL, Capaldi FR, Azevedo RA. Antioxidant metabolism in coffee (Coffea arabica L.) plants in response to nitrogen supply. Theor Exp Plant Phys. 2015;27(3-4):203-13.

38. Chrysargyris A, Panayiotou C, Tzortzakis N. Nitrogen and phosphorus levels affected plant growth, essential oil composition and antioxidant status of lavender plant (Lavandula angustifolia mill.). Ind Crop Prod. 2016;83:577-86.

39. Jauffrais $T$, Jesus $B$, Méléder $V$, Turpin $V$, Arnaldo $D$, Raimbault $P$, Jézéquel VM. Physiological and photophysiological responses of the benthic diatom Entomoneis paludosa (Bacillariophyceae) to dissolved inorganic and organic nitrogen in culture. Mar Biol. 2016;163(5):115.

40. Fernandes J, Chaloub RM, Reinert F. Influence of nitrogen supply on the photoprotective response of Neoregelia cruenta under high and low light intensity. Funct Plant Biol. 2002;29(6):757-62.

41. Scheible W, Morcuende R, Czechowski T, Fritz C, Osuna D, Palacios-Rojas N, Schindelasch D, Thimm O, Udvardi MK, Stitt M. Genome-wide reprogramming of primary and secondary metabolism, protein synthesis, cellular growth processes, and the regulatory infrastructure of Arabidopsis in response to nitrogen. Plant Physiol. 2004;136(1):2483-99.

42. Zhang Y, Wu H, Sun M, Peng Q, Li A. Photosynthetic physiological performance and proteomic profiling of the oleaginous algae Scenedesmus acuminatus reveal the mechanism of lipid accumulation under low and high nitrogen supplies. Photosynth Res. 2018;138(1):73-102.

43. Krapp A, Berthomé R, Orsel M, Mercey-Boutet S, Yu A, Castaings L, Elftieh S, Major H, Renou J, Daniel-Vedele F. Arabidopsis roots and shoots show distinct temporal adaptation patterns toward nitrogen starvation. Plant Physiol. 2011;157(3):1255-82.

44. Bi YM, Zhang Y, Signorelli T, Zhao R, Zhu T, Rothstein S. Genetic analysis of Arabidopsis GATA transcription factor gene family reveals a nitrate-inducible member important for chlorophyll synthesis and glucose sensitivity. Plant J. 2005;44(4):680-92

45. Martindale W, Leegood RC. Acclimation of photosynthesis to low temperature in Spinacia oleracea L. II. Effects of nitrogen supply. J Exp Bot. 1997;48(10):1873-80.

46. Kimura A, Eaton-Rye JJ, Morita EH, Nishiyama Y, Hayashi H. Protection of the oxygen-evolving machinery by the extrinsic proteins of photosystem II is essential for development of cellular thermotolerance in Synechocystis sp. PCC 6803. Plant Cell Physiol. 2002;43(8):932-8.

47. Li X, BjoËrkman O, Shih C, Grossman AR, Rosenquist M, Jansson S, Niyogi KK. A pigment-binding protein essential for regulation of photosynthetic light harvesting. Nature. 2000;403(6768):391.

48. Zhang R, Sun Y, Liu Z, Jin W, Sun Y. Effects of melatonin on seedling growth, mineral nutrition, and nitrogen metabolism in cucumber under nitrate stress. J Pineal Res. 2017;62(4):e12403.
49. Liu D, Cui XM, Wang CL, Lu F, He CF. Preliminary study on the photosynthetic characteristics of Panax notoginseng. Southwest China J Agric Sci. 1992;2:41-3 (In Chinese).

50. Chen J, Kuang S, Long G, Yang S, Meng Z, Li L, Chen Z, Zhang G. Photosynthesis, light energy partitioning, and photoprotection in the shade-demanding species Panax notoginseng under high and low level of growth irradiance. Funct Plant Biol. 2016;43(6):479-91.

51. Xu XZ, Zhang JY, Zhang GH, Long GQ, Yang SC, Chen ZJ, Wei FG, Chen JW. Effects of light intensity on photosynthetic capacity and light energy allocation in Panax notoginseng. Chin J Appl Ecol. 2018;29(1):193-204 (In (hinese).

52. Kuang SB, Xu XZ, Yang SC, Zhang GH, Meng ZG, Long GQ, Chen ZJ, Chen JW. Effects of different light qualities and transmittances on growth of Panax notoginseng seedlings. Southwest China J of Agric Sci. 2014;45:193542 (In Chinese).

53. Wei ML, Sun YQ, Huang TW, Wang BY, Chen ZJ, Wang CL. Effects on the growth and the contents of saponins with different level of nitrogen applied in Panax notoginseng. Res Pract Chin Med. 2008;22:17-20 (In Chinese).

54. Yang YJ, Cui XM, Yang T, Xiao FH. Good agricultural practice and developmental strategy for Panax notoginseng cultivated in Wenshang. J Yunnan Agric Univ. 2008:23:402-6 (In Chinese).

55. Ou XH, Jin H, Guo LP, Yang Y, Cui XM, Xiao YB, Liu DH. Status and prospective on nutritional physiology and fertilization of Panax notoginseng. China J Chin Mater Med. 2011;36:2620-4 (In Chinese).

56. Zheng JF, Yin ZB, Zhao Z, Mao ZS, Wei W, Wei FG, Chen ZJ, He XH, Zhu SS. Role of nitrogen and phosphorus fertilizer on seedling production of Panax notoginseng. J Yunnan Agric Univ. 2017;32:113-9 (In Chinese).

57. Wang CL, Chen ZJ, Sun YQ, Wang BY, Wei ML, Huang TW. Effect of different proportion fertilizer on the growth and yield of Panax notoginseng. Res Pract Chin Med. 2007;1:5-7 (In Chinese).

58. Ou XH, Zhang ZH, Zheng DM, Guo LP, Wang L, Wang JJ, Liu DH. Effects of nitrogen fertilizer regimes on yield, quality, nutrition uptake and distribution of biennial Panax notoginseng. Mod Chin Med. 2014;16:1000-5 (In Chinese).

59. Kogami H, Hanba YT, Kibe T, Terashima I, Masuzawa T. $\mathrm{CO}_{2}$ transfer conductance, leaf structure and carbon isotope composition of Polygonum cuspidatum leaves from low and high altitudes. Plant Cell Environ. 2001; 24(5):529-38.

60. Ren T, Weraduwage SM, Sharkey TD. Prospects for enhancing leaf photosynthetic capacity by manipulating mesophyll cell morphology. J Exp Bot. 2018;70(4):1153-65.

61. Hanba YT, Shibasaka M, Hayashi Y, Hayakawa T, Kasamo K, Terashima I, Katsuhara M. Overexpression of the barley aquaporin HVPIP2; 1 increases internal $\mathrm{CO}_{2}$ conductance and $\mathrm{CO}_{2}$ assimilation in the leaves of transgenic rice plants. Plant Cell Physiol. 2004:45(5):521-9.

62. Xiong D, Liu XI, Liu L, Douthe C, Li Y, Peng S, Huang J. Rapid responses of mesophyll conductance to changes of $\mathrm{CO}_{2}$ concentration, temperature and irradiance are affected by $\mathrm{N}$ supplements in rice. Plant Cell Environ. 2015; 38(12):2541-50.

63. Tosens T, Laanisto L. Mesophyll conductance and accurate photosynthetic carbon gain calculations. J Exp Bot. 2018;69(22):5315-8.

64. Kebeish R, Niessen M, Thiruveedhi K, Bari R, Hirsch H, Rosenkranz R, Stäbler N, Schönfeld B, Kreuzaler F, Peterhänsel C. Chloroplastic photorespiratory bypass increases photosynthesis and biomass production in Arabidopsis thaliana. Nat Biotechnol. 2007;25(5):593.

65. Rasulov B, Talts E, Niinemets Ü. Spectacular oscillations in plant isoprene emission under transient conditions explain the enigmatic $\mathrm{CO}_{2}$ response. Plant Physiol. 2016;172(4):2275-85.

66. Farquhar GD, Busch FA. Changes in the chloroplastic $\mathrm{CO}_{2}$ concentration explain much of the observed Kok effect: a model. New Phytol. 2017;214(2): $570-84$

67. Yin X, Struik PC. Can increased leaf photosynthesis be converted into higher crop mass production? A simulation study for rice using the crop model GECROS. J Exp Bot. 2017;68(9):2345-60.

68. Onoda Y, Wright IJ, Evans JR, Hikosaka K, Kitajima K, Niinemets Ü, Poorter H, Tosens T, Westoby M. Physiological and structural tradeoffs underlying the leaf economics spectrum. New Phytol. 2017;214(4):1447-63.

69. Liu T, Lu JW, Ren T, Li XK, Cong RH. Relationship between photosynthetic nitrogen use efficiency and nitrogen allocation in photosynthetic apparatus of winter oilseed rape under different nitrogen levels. Plant Nutr Fert Sci. 2016:22:518-24 (In Chinese). 
70. Hou W, Tränkner M, Lu J, Yan J, Huang S, Ren T, Cong R, Li X. Interactive effects of nitrogen and potassium on photosynthesis and photosynthetic nitrogen allocation of rice leaves. BMC Plant Biol. 2019;19(1):302.

71. Erb TJ, Zarzycki J. A short history of RubisCO: the rise and fall (?) of Nature's predominant $\mathrm{CO}_{2}$ fixing enzyme. Curr Opin Biotech. 2018;49:100-7.

72. Farquhar GD, von Caemmerer SV, Berry JA. A biochemical model of photosynthetic $\mathrm{CO}_{2}$ assimilation in leaves of C3 species. Planta. 1980;149(1): 78-90.

73. Salesse-Smith CE, Sharwood RE, Busch FA, Kromdijk J, Bardal V, Stern DB. Overexpression of Rubisco subunits with RAF1 increases Rubisco content in maize. Nat Plants. 2018;4(10):802.

74. Cousins $\mathrm{AB}$, Bloom AJ. Influence of elevated $\mathrm{CO}_{2}$ and nitrogen nutrition on photosynthesis and nitrate photo-assimilation in maize (Zea mays L.). Plant Cell Environ. 2003;26(9):1525-30.

75. Chikov VI, Abdrakhimov FA, Batasheva SN, Khamidullina LA. Characteristics of photosynthesis in maize leaves (C4 plants) upon changes in the level of illuminance and nitrate nutrition. Russ J Plant Physl. 2016;63(5):620-5.

76. Lin MT, Occhialini A, Andralojc PJ, Parry MA, Hanson MR. A faster Rubisco with potential to increase photosynthesis in crops. Nature. 2014;513(7519):547.

77. Li Y, Yang X, Ren B, Shen Q, Guo S. Why nitrogen use efficiency decreases under high nitrogen supply in rice (Oryza sativa L.) seedlings. J Plant Growth Regul. 2012;31(1):47-52.

78. Córdoba J, Molina-Cano J, Martínez-Carrasco R, Morcuende R, Pérez P. Functional and transcriptional characterization of a barley mutant with impaired photosynthesis. Plant Sci. 2016;244:19-30.

79. Ding L, Gao L, Liu W, Wang M, Gu M, Ren B, Xu G, Shen Q, Guo S. Aquaporin plays an important role in mediating chloroplastic $\mathrm{CO}_{2}$ concentration under high-N supply in rice (Oryza sativa) plants. Physiol Plantarum. 2016;156(2):215-26.

80. Amiour N, Imbaud S, Clément G, Agier N, Zivy M, Valot BT, Balliau T, Armengaud P, Quilleré I, Ca AR. The use of metabolomics integrated with transcriptomic and proteomic studies for identifying key steps involved in the control of nitrogen metabolism in crops such as maize. J Exp Bot. 2012; 63(14):5017-33.

81. Bielczynski LW, Cki MK, Hoefnagels I, Gambin A, Croce R. Leaf and plant age affects photosynthetic performance and photoprotective capacity. Plant Physiol. 2017;175(4):1634-48.

82. Ferroni L, Suorsa M, Aro EM, Baldisserotto C, Pancaldi S. Light acclimation in the lycophyte $S$ elaginella martensii depends on changes in the amount of photosystems and on the flexibility of the light-harvesting complex II antenna association with both photosystems. New Phytol. 2016;211(2):554-68.

83. Bonardi V, Pesaresi P, Becker T, Schleiff E, Wagner R, Pfannschmidt T, Jahns $P$, Leister D. Photosystem II core phosphorylation and photosynthetic acclimation require two different protein kinases. Nature. 2005:437(7062):1179.

84. Song $Q$, Wang $Y$, Qu M, Ort DR, Zhu XG. The impact of modifying photosystem antenna size on canopy photosynthetic efficiency-development of a new canopy photosynthesis model scaling from metabolism to canopy level processes. Plant Cell Environ. 2017;40(12):2946-57.

85. Jia Y, Gray VM. Interrelationships between nitrogen supply and photosynthetic parameters in Vicia faba L. Photosynthetica. 2003:41(4):605-10.

86. Nishiyama Y, Yamamoto $\mathrm{H}$, Allakhverdiev SI, Inaba M, Yokota A, Murata N. Oxidative stress inhibits the repair of photodamage to the photosynthetic machinery. EMBO J. 2001;20(20):5587-94.

87. Chen J, Yang Z, Zhou P, Hai M, Tang T, Liang Y, An T. Biomass accumulation and partitioning, photosynthesis, and photosynthetic induction in fieldgrown maize (Zea mays L.) under low-and high-nitrogen conditions. Acta Physiol Plant. 2013;35(1):95-105.

88. Guo J, Yang Y, Wang G, Yang L, Sun X. Ecophysiological responses of Abies fabri seedlings to drought stress and nitrogen supply. Physiol Plantarum. 2010;139(4):335-47.

89. Iqbal N, Nazar R, Syeed S, Masood A, Khan NA. Exogenously-sourced ethylene increases stomatal conductance, photosynthesis, and growth under optimal and deficient nitrogen fertilization in mustard. J Exp Bot. 2011;62(14):4955-63.

90. Tosens T, Nishida K, Gago J, Coopman RE, Cabrera HM, Carriquí M, Laanisto L, Morales L, Nadal M, Rojas R. The photosynthetic capacity in 35 ferns and fern allies: mesophyll $\mathrm{CO}_{2}$ diffusion as a key trait. New Phytol. 2016;209(4):1576-90.

91. Xu S, Liu L, Woo KC, Wang D. Changes in photosynthesis, xanthophyll cycle, and sugar accumulation in two North Australia tropical species differing in leaf angles. Photosynthetica. 2007;45(3):348.
92. Hidema J, Makino A, Kurita Y, Mae T, Ojima K. Changes in the levels of chlorophyll and light-harvesting chlorophyll a/b protein of PS II in rice leaves aged under different irradiances from full expansion through senescence. Plant Cell Physiol. 1992;33(8):1209-14.

93. Hubbart S, Ajigboye OO, Horton P, Murchie EH. The photoprotective protein PsbS exerts control over $\mathrm{CO}_{2}$ assimilation rate in fluctuating light in rice. Plant J. 2012;71(3):402-12.

94. Verhoeven AS, Demmig-Adams B, Adams WW III. Enhanced employment of the xanthophyll cycle and thermal energy dissipation in spinach exposed to high light and N stress. Plant Physiol. 1997;113(3):817-24.

95. Muchecheti F, Madakadze C, Soundy P. Leaf chlorophyll readings as an indicator of nitrogen status and yield of spinach (Spinacia oleracea L.) grown in soils amended with prunings. J Plant Nutr. 2016;39(4):539-61.

96. Ruban A, Lavaud J, Rousseau B, Guglielmi G, Horton P, Etienne A. The superexcess energy dissipation in diatom algae: comparative analysis with higher plants. Photosynth Res. 2004;82(2):165.

97. Vidhyavathi R, Venkatachalam L, Sarada R, Ravishankar GA. Regulation of carotenoid biosynthetic genes expression and carotenoid accumulation in the green alga Haematococcus pluvialis under nutrient stress conditions. J Exp Bot. 2008;59(6):1409-18.

98. Grünewald K, Eckert M, Hirschberg J, Hagen C. Phytoene desaturase is localized exclusively in the chloroplast and up-regulated at the mRNA level during accumulation of secondary carotenoids in Haematococcus pluvialis (Volvocales, Chlorophyceae). Plant Physiol. 2000;122(4):1261-8.

99. Horton P, Ruban AV, Walters RG. Regulation of light harvesting in green plants. Annu Rev Plant Biol. 1996;47(1):655-84

100. Li X, Müller-Moulé P, Gilmore AM, Niyogi KK. PsbS-dependent enhancement of feedback de-excitation protects photosystem II from photoinhibition. Proc Natl Acad Sci. 2002;99(23):15222-7.

101. Alt DS, Doyle JW, Malladi A. Nitrogen-source preference in blueberry (Vaccinium sp.): Enhanced shoot nitrogen assimilation in response to direct supply of nitrate. J Plant Physiol. 2017;216:79-87.

102. Noctor G, Foyer $\mathrm{CH}$. A re-evaluation of the ATP: NADPH budget during C3 photosynthesis: a contribution from nitrate assimilation and its associated respiratory activity? J Exp Bot. 1998;49(329):1895-908.

103. Neto MCL, Lobo AK, Martins MO, Fontenele AV, Silveira JAG. Dissipation of excess photosynthetic energy contributes to salinity tolerance: a comparative study of salt-tolerant Ricinus communis and salt-sensitive Jatropha curcas. J Plant Physiol. 2014;171(1):23-30.

104. Walker BJ, Strand DD, Kramer DM, Cousins AB. The response of cyclic electron flow around photosystem I to changes in photorespiration and nitrate assimilation. Plant Physiol. 2014;165(1):453-62.

105. Sun X, Jia X, Huo L, Che R, Gong X, Wang P, Ma F. MdATG18a overexpression improves tolerance to nitrogen deficiency and regulates anthocyanin accumulation through increased autophagy in transgenic apple. Plant Cell Environ. 2018;41(2):469-80.

106. Buckley TN, Diaz EA. Reporting estimates of maximum potential electron transport rate. New Phytol. 2015;205(1):14-7

107. Baker NR. Chlorophyll fluorescence: a probe of photosynthesis in vivo. Annu Rev Plant Biol. 2008;59:89-113.

108. Miyake C, Horiguchi S, Makino A, Shinzaki Y, Yamamoto H, Tomizawa K. Effects of light intensity on cyclic electron flow around PSI and its relationship to non-photochemical quenching of $\mathrm{Chl}$ fluorescence in tobacco leaves. Plant Cell Physiol. 2005;46(11):1819-30.

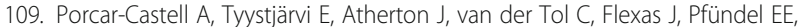
Moreno J, Frankenberg C, Berry JA. Linking chlorophyll a fluorescence to photosynthesis for remote sensing applications: mechanisms and challenges. J Exp Bot. 2014;65(15):4065-95.

110. Evans JR, Poorter H. Photosynthetic acclimation of plants to growth irradiance: the relative importance of specific leaf area and nitrogen partitioning in maximizing carbon gain. Plant Cell Environ. 2001;24(8):755-67.

111. Bota J, Medrano H, Flexas J. Is photosynthesis limited by decreased Rubisco activity and RuBP content under progressive water stress? New Phytol. 2004;162(3):671-81.

112. Souza RP, Machado EC, Silva JAB, Lag^oa AMMA, Silveira JAG. Photosynthetic gas exchange, chlorophyll fluorescence and some associated metabolic changes in cowpea (Vigna unguiculata) during water stress and recovery. Environ Exp Bot. 2004;51(1):45-56.

113. Yamaguchi K, Nishimura M. Reduction to below threshold levels of glycolate oxidase activities in transgenic tobacco enhances photoinhibition during irradiation. Plant Cell Physiol. 2000;41(12):1397-406. 
114. Huang $W, H u H$, Zhang SB. Photorespiration plays an important role in the regulation of photosynthetic electron flow under fluctuating light in tobacco plants grown under full sunlight. Front Plant Sci. 2015;6:621.

115. Valentini R, Epron D, De Angelis P, Matteucci G, Dreyer E. In situ estimation of net $\mathrm{CO}_{2}$ assimilation, photosynthetic electron flow and photorespiration in Turkey oak (Q. cerris L.) leaves: diurnal cycles under different levels of water supply. Plant Cell Environ. 1995;18(6):631-40.

116. Manter DK, Kerrigan J. $A / C_{i}$ curve analysis across a range of woody plant species: influence of regression analysis parameters and mesophyll conductance. J Exp Bot. 2004;55(408):2581-8.

117. Thayer SS, Björkman O. Leaf xanthophyll content and composition in sun and shade determined by HPLC. Photosynth Res. 1990;23(3):331-43.

118. Niinemets Ü, Tenhunen JD. A model separating leaf structural and physiological effects on carbon gain along light gradients for the shadetolerant species Acer saccharum. Plant Cell Environ. 1997;20(7):845-66.

119. Makino A, Mae T, Ohira K. Photosynthesis and ribulose-1, 5-bisphosphate carboxylase/oxygenase in rice leaves from emergence through senescence. Quantitative analysis by carboxylation/oxygenation and regeneration of ribulose 1, 5-bisphosphate. Planta. 1985;166(3):414-20.

120. Parry M, Andralojc PJ, Parmar S, Keys AJ, Habash D, Paul MJ, Alred R, Quick WP, Servaites JC. Regulation of Rubisco by inhibitors in the light. Plant Cell Environ. 1997:20(4):528-34

121. Brunner AM, Yakovlev IA, Strauss SH. Validating internal controls for quantitative plant gene expression studies. BMC Plant Biol. 2004;4(1):14

122. Livak KJ, Schmittgen TD. Analysis of relative gene expression data using real-time quantitative PCR and the $2^{-\Delta \Delta \mathrm{ct}}$ method. Methods. 2001;25(4): $402-8$.

\section{Publisher's Note}

Springer Nature remains neutral with regard to jurisdictional claims in published maps and institutional affiliations.

Ready to submit your research? Choose BMC and benefit from:

- fast, convenient online submission

- thorough peer review by experienced researchers in your field

- rapid publication on acceptance

- support for research data, including large and complex data types

- gold Open Access which fosters wider collaboration and increased citations

- maximum visibility for your research: over $100 \mathrm{M}$ website views per year

At $\mathrm{BMC}$, research is always in progress.

Learn more biomedcentral.com/submissions 